\title{
A Comprehensive Review on Valorization of Agro-Food Industrial Residues by Solid-State Fermentation
}

\author{
Gordana Šelo (D), Mirela Planinić, Marina Tišma (D), Srećko Tomas, Daliborka Koceva Komlenić \\ and Ana Bucić-Kojić *
}

Citation: Šelo, G.; Planinić, M.;

Tišma, M.; Tomas, S.; Koceva

Komlenić, D.; Bucić-Kojić, A. A

Comprehensive Review on

Valorization of Agro-Food Industrial Residues by Solid-State Fermentation Foods 2021, 10, 927. https://doi.org/ 10.3390 / foods 10050927

Academic Editor: Nuno Mateus

Received: 18 March 2021

Accepted: 21 April 2021

Published: 23 April 2021

Publisher's Note: MDPI stays neutral with regard to jurisdictional claims in published maps and institutional affiliations.

Copyright: (c) 2021 by the authors. Licensee MDPI, Basel, Switzerland. This article is an open access article distributed under the terms and conditions of the Creative Commons Attribution (CC BY) license (https:// creativecommons.org/licenses/by/ $4.0 /)$.
Faculty of Food Technology Osijek, Josip Juraj Strossmayer University of Osijek, Franje Kuhača 18, HR-31000 Osijek, Croatia; gselo@ptfos.hr (G.Š.); mplanini@ptfos.hr (M.P.); mtisma@ptfos.hr (M.T.); stomas@ptfos.hr (S.T.); dkoceva@ptfos.hr (D.K.K.)

* Correspondence: abucic@ptfos.hr

\begin{abstract}
Agro-food industrial residues (AFIRs) are generated in large quantities all over the world The vast majority of these wastes are lignocellulosic wastes that are a source of value-added products. Technologies such as solid-state fermentation (SSF) for bioconversion of lignocellulosic waste, based on the production of a wide range of bioproducts, offer both economic and environmental benefits. The versatility of application and interest in applying the principles of the circular bioeconomy make SSF one of the valorization strategies for AFIRs that can have a significant impact on the environment of the wider community. Important criteria for SSF are the selection of the appropriate and compatible substrate and microorganism, as well as the selection of the optimal process parameters for the growth of the microorganism and the production of the desired metabolites. This review provides an overview of the management of AFIRs by SSF: the current application, classification, and chemical composition of AFIRs; the catalytic function and potential application of enzymes produced by various microorganisms during SSF cultivation on AFIRs; the production of phenolic compounds by SSF; and a brief insight into the role of SSF treatment of AFIRs for feed improvement and biofuel production.
\end{abstract}

Keywords: lignocellulosic biomass; value-added products; bioactive compounds; biofuels; feed

\section{Introduction}

The term "residue" includes materials that are not intentionally generated in the production process but are not necessarily considered waste [1]. Significant amounts of residues are generated during the processing of plant raw materials that are transformed into final products, e.g., in wine production and grain processing, residues account for about $30 \%$ of the processed raw material mass [2,3]. They are treated as waste and their unregulated disposal into the environment can cause serious environmental problems [4]. AFIRs are a wide variety of biomass, including pomace, fruit, and vegetable peels; husks, bran, and germ of cereals; pods; stalks; and pomace left over after oil production. Due to their chemical composition, they are rich sources of high value components such as polysaccharides, proteins (including enzymes), dietary fibers, fatty acids, flavors and aromas, and bioactive compounds [5-8]. High-value components refer to components that have health-promoting properties and a wide range of potential industrial applications (pharmaceutical, food, and cosmetic industries) due to their biological activity or nutritional value $[5,6]$.

AFIRs are mostly lignocellulosic materials composed of three polymers: cellulose (40-50\%), hemicellulose (20-30\%), and lignin (20-35\%). Lignin is the main component of the cell wall $[9,10]$. According to numerous studies, SSF is one of the most suitable techniques to obtain the desired biomolecules from lignocellulosic materials. SSF has been extensively studied for potential applications in fuel, food, and feed, as well as in the chemical and pharmaceutical industries [11,12]. 
By-products from lignocellulosic biomass are an important alternative energy source, playing an important role in the circular bioeconomy. The management of this resource promotes the reuse of raw materials, high industrial production yields, and the generation of minimal waste [13]. The efficient use of natural resources, the development of new technologies, and the improvement of existing ones increase the value of agricultural waste. Their use in the production of biogas, biofuels, biofertilizers, bioactive compounds, and pharmaceuticals is consistent with sustainable development and the business model of using agricultural waste in the bioeconomy. SSF can be applied as a technique of biological processing of different lignocellulosic materials to obtain different products following the concept of the 3-R approach "reduce, reuse, recycle" [14], thus contributing to the circular bioeconomy [15].

This paper provides a comprehensive overview of the possibilities of valorization of lignocellulosic biomass produced in the agro-food industry. Particular attention is paid to the composition of the different types of AFIRs, taking into account that they come in different forms and in many processing routes. SSF experiments on the valorization of AFIRs for the production of enzymes (ligninolytic and hydrolytic enzymes) and a wide number of value-added products through the use of different microorganisms are discussed. In addition, the valorization of lignocellulosic biomass treated with microorganisms for use in feed and biofuel production is presented.

\section{Agro-Food Industrial Residues}

The increasing expansion of agro-industrial activities in recent decades has resulted in the accumulation of a large amount of lignocellulosic residues (wastes or by-products) worldwide, which are not properly disposed of and thus contribute to climate change, as well as soil, water, and air pollution $[16,17]$. An estimated one-third $(\approx 1.3$ billion tonnes) of food produced for human consumption is wasted annually worldwide [18]. Although some of these residues are used as animal feed, large quantities are disposed of in landfills or incinerated [17]. In general, AFIRs can be divided into agricultural residues and food industry residues (Figure 1). This review does not cover food waste, which includes unsold food, leftovers, and uneaten food from households and restaurants, as well as from large-scale producers such as caterers and supermarkets [19].

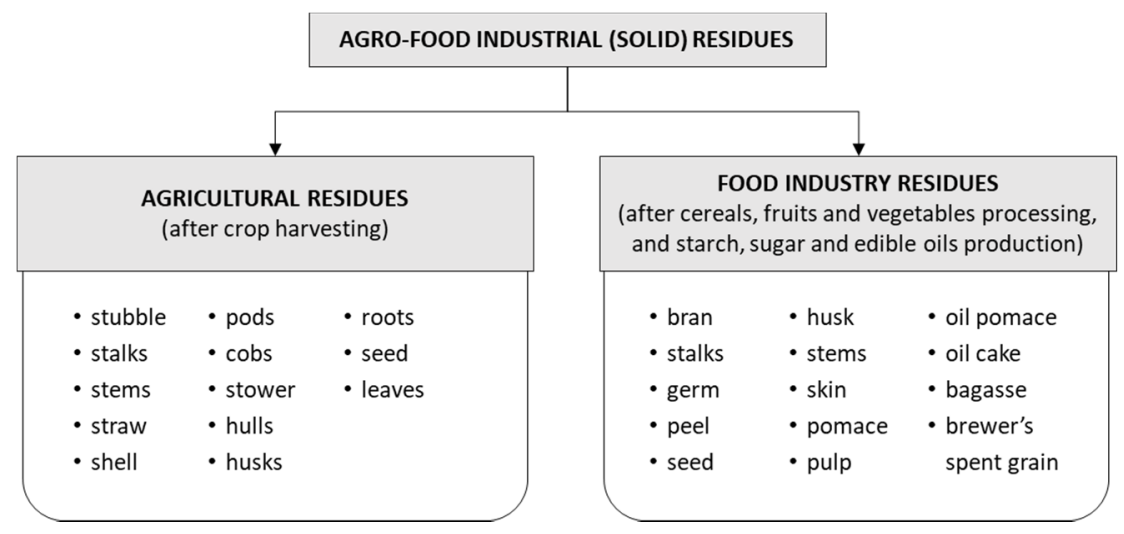

Figure 1. Classification of AFIR.

\subsection{Agricultural Residues}

Agricultural residues include the waste left on fields after harvesting and the waste after processing of raw materials (pods, stubble, stems, stalks, leaves, shell, straw, seeds, husks, roots, etc.) (Figure 1). Harvest residues represent an alternative to generate large amounts of energy in the future [20]. Some examples of widely used agricultural residues are straw from cereals (wheat, barley, oats, rye, rice, spelt), barley hulls, soybean stalks, corn cobs, corn stalks, sunflower stalks, sunflower seed hulls, etc., and their chemical compositions are presented in Table 1 . The type of cereal grains and their residues produced 
worldwide depends on economic, cultural, and environmental factors. The average annual production of cereals is 2.435 million tonnes (data for the period 2008-2017) [21]. Water availability and temperature are the most important environmental factors that can affect grain production.

Table 1. Chemical composition of common agricultural residues.

\begin{tabular}{|c|c|c|c|c|c|}
\hline $\begin{array}{l}\text { Agricultural } \\
\text { Residues }\end{array}$ & Lignin, $\%_{\mathrm{db}}$ & Cellulose, $\%_{\mathrm{db}}$ & $\begin{array}{c}\text { Hemicellulose, } \\
\%_{\mathrm{db}}\end{array}$ & Ash, $\%_{d b}$ & Reference \\
\hline Barley husk & 22.0 & 39.0 & 12.0 & 7.0 & {$[22,23]$} \\
\hline Barley straw & $9.6-13.8$ & $33.8-46.8$ & $21.9-30.0$ & 4.4 & {$[5,24,25]$} \\
\hline Corn cob & 6.1 & 33.7 & 31.9 & 8.5 & {$[5,24]$} \\
\hline Corn stalks & $7.0-7.3$ & $35.0-39.0$ & $16.8-42.0$ & 24.9 & {$[5,25]$} \\
\hline Oat straw & $4.1-23.6$ & $31.7-39.4$ & $23.3-28.2$ & 3.2 & {$[5,24,26]$} \\
\hline Rice straw & $8.3-9.9$ & $19.6-36.2$ & $19.0-50.4$ & 14.7 & {$[5,25,27]$} \\
\hline Rye straw & $19.0-30.8$ & $37.4-37.6$ & 30.5 & 5.7 & {$[5,26,28]$} \\
\hline Soybean stalks & 19.8 & 34.5 & 24.8 & ND & [29] \\
\hline Spelt straw & 14.8 & 38.3 & 24.3 & 5.7 & [30] \\
\hline Sunflower seed hulls & 29.4 & 29.4 & 29.4 & 2.1 & {$[26,29]$} \\
\hline Sunflower stalks & $13.4-17.5$ & $38.5-42.1$ & $29.7-33.5$ & $8.6-9.2$ & {$[5,27]$} \\
\hline Wheat straw & $8.9-22.1$ & $32.9-49.8$ & $23.7-25.0$ & $3.6-4.7$ & {$[5,24,25,31,32]$} \\
\hline
\end{tabular}

$\%_{\mathrm{db}}$ - percentage of the dry solids (dry basis); ND—not determined.

\subsection{Food industry Residues}

Residues resulting from the processing of raw materials in the various food industries (fruit industry, beer industry, oil industry, cereal-processing industry) consist of pips, skins, stalks, pomace, oil cake, oil pomace, brewer's grains, bran, germ, etc. (Figure 1). Grape pomace, apple pomace, wheat bran, rye bran, rice bran, hull-less pumpkin oil cake, hemp oil cake, and flax oil cake are some examples of residues from the food industry that are produced in significant quantities and can be used for various energy sources and to produce a variety of valuable compounds. The chemical composition of common food industry residues is presented in Table 2. EU processed food producers have to comply with the conditions of the EU environmental policy regarding the recycling or disposal of the generated residues [28]. Grape pomace, which is a by-product of wine production, and cereal residues, which are a by-product of grain processing, are representative examples of the production of value-added compounds from industrial food residues [3,33].

Vitis vinifera is one of the most widely grown crops in the world, with an average annual production of 71 million tons (data for period 2008-2017) [21]. It is estimated that about $80 \%$ of the annual grape yield is processed into wine, while $20-30 \%$ of the processed grapes remain as grape pomace (grape marc). It has been found that only $30 \%$ of the phenolic compounds are extracted into the wine during winemaking, while $70 \%$ of the bioactive phenolic compounds remain in the grape pomace [34]. The reason for this is the high content of polymeric proanthocyanidins in the grape pomace and of bound phenolic compounds in complexes with the proteins, fibers, and polysaccharides, which are difficult to extract unless pretreatment is carried out (acid, alkali, biological treatment, etc.) [35].

Grape pomace consists of seeds, skin, and sometimes stems. According to the literature, the ratio of grape seeds in grape pomaces varies in the range of $15-52 \% \mathrm{db}$, while the proportion of grape skins can be as high as $65 \% \mathrm{db}$ [2]. Grape pomace can be a good substrate in SSF due to its composition, changing the properties of grape pomace. According to the available studies, grape pomace is generally considered a good source of polyphenolic compounds [36], although there are studies on the production of enzymes [33] and biofuels from grape pomace.

The term cereals refers to nine species: wheat, rye, barley, oats, rice, millet, corn, sorghum, and triticale (a hybrid of wheat and rye). Cereals consists of hull and kernel, where kernel consists of bran, germ, and endosperm [31]. The cereal processing industry produces $30 \%$ of the residues (hull, bran), which are mainly represented by bran. The bran 
is separated during milling of the grain [32]. Wheat and oat whole grains are known to be a rich source of phenolic compounds that exhibit significant antioxidant activity. The predominant phenolic compounds are phenolic acids and flavonoids, with the highest concentrations found in the bran, but still they have reduced bioavailability [3].

Table 2. Chemical composition of common food industry residues.

\begin{tabular}{|c|c|c|c|c|c|c|}
\hline Food Industry Residues & Lignin, $\%_{\mathrm{db}}$ & Cellulose, $\%_{\mathrm{db}}$ & Hemicellulose, $\%_{\mathrm{db}}$ & Protein, $\%_{\mathrm{db}}$ & Ash, $\%_{\mathrm{db}}$ & Reference \\
\hline Apple pomace & $14.8-22.4$ & 47.5 & 27.8 & $6.0-7.0$ & $1.1-5.1$ & {$[37,38]$} \\
\hline Brewers spent grain & $4-27.8$ & $13.14-16.8$ & $28.4-39.0$ & $23.4-27.4$ & $3-5$ & {$[39,40]$} \\
\hline Flax oil cake & 6.0 & 8.2 & 4.6 & 32.8 & 5.3 & [41] \\
\hline Grape pomace & $11.6-41.3$ & $9.2-14.5$ & $4.0-10.3$ & $7.0-23.5$ & $4.7-9.5$ & {$[42,43]$} \\
\hline Hemp oil cake & 16.7 & 22.5 & 14.2 & 24.8 & 7.5 & [41] \\
\hline Hull-less pumpkin oil cake & 0.7 & 4.4 & 6.7 & 38.3 & 7.8 & [41] \\
\hline Olive mill waste & $13.3-15.8$ & $24.8-33.8$ & $13-16.3$ & $6.7-7.2$ & $2.5-8.9$ & {$[44,45]$} \\
\hline Rice bran & 24.8 & 34.0 & 28.2 & $5.8-8.3$ & ND & [46] \\
\hline Rye bran & $3.5-4.4$ & $5.0-6.0$ & ND & $14.4-18$ & $2.8-6.2$ & {$[22,47]$} \\
\hline Sugarcane bagasse & $18.9-26.1$ & $36.9-45.7$ & $25.60-29.58$ & 2.18 & 2.84 & {$[48,49]$} \\
\hline Wheat bran & $3.0-5.0$ & $9.0-12.0$ & 38.9 & $9.6-18.7$ & $0.04-8.1$ & [50-52] \\
\hline
\end{tabular}

$\%$ - percentage of the dry solids (dry basis); ND—not determined.

\subsection{Chemical Composition of AFIRs}

On the basis of the carbon source, Mitchell et al. [53] classify substrates for SSF into three groups: starch substrates (contain starch as the main carbon source), lignocellulosic substrates (contain cellulose and lignocellulose as the main carbon source), and substrates containing mainly soluble sugars. Most AFIRs are classified as lignocellulosic biomass. Generally, AFIRs contain a high content of polysaccharides such as cellulose, hemicellulose, and lignin, but also contain other nutrients such as proteins, lipids, pectin, and polyphenols [54]. A literature overview of the chemical composition of AFIRs derived from various sources is presented in Tables 1 and 2.

Such material is complex and heterogeneous, as can be seen from its chemical composition. Agronomic measures of cultivation, weather conditions, variety, harvesting methods, storage conditions, and the analytical methods used to measure the individual components are all factors that influence the chemical composition of the material.

Commonly used analytical methods to determine the chemical composition of such material are ash determination (total combustion in a muffle furnace), determination of total organic carbon [55], total proteins (Kjeldahl method) [56], free fats (direct solvent extraction), neutral detergent fibers (NDF), acid detergent fibers (ADF), acid detergent lignin (ADL) determination by Van Soest [55], acid-insoluble lignin (Klason lignin) determination by gravimetric assay, total polyphenolic compounds determination by the Folin-Ciocalteu colorimetric method [57], and individual polyphenolic compounds determination by UHPLC [58], among others.

Lignocellulosic structure of AFIRs can be disrupted by biocatalytic activities of different microorganisms. In order for one to choose the best method (microorganism, type of cultivation, process conditions, etc.) for its reuse, such residues should be firstly chemically characterized.

\section{Solid-State Fermentation (SSF)}

\subsection{General}

SSF is a fermentation process in which microorganisms grow on moist, solid material under controlled conditions, without the presence of free water or with a minimal amount of free water. Inert or non-inert materials can be used as solid substrate in SSF processes [59]. AFIRs are among the non-inert solid substrates that serve as nutrients for microbial growth and metabolite production. After fermentation, they can also be the product of fermentation, used for feed or biofuel production.

The microorganisms used in SSF are filamentous fungi, yeasts, and bacteria. Due to their physiological, biochemical, and enzymatic properties, filamentous fungi (multicellular 
organisms) are the most commonly used, especially those from fungal kingdom subdivision Basidiomycota and Ascomycota [60,61]. In order to develop a reliable and repeatable SSF process, researchers should carry out this process in specific types of bioreactors under controlled conditions, such as tray bioreactors, rotating disc reactors, fixed bed bioreactors, column bioreactors, air pressure pulsation solid state bioreactors, rotating horizontal drum bioreactors, stirred drum bioreactors, fluidized bed bioreactors, air-lift bioreactors, and immersion bioreactors $[8,62]$. The most suitable type of bioreactor for SSF scale-up is the tray bioreactor. It is a traditional type of bioreactor used in SSF, most commonly in laboratory research for enzyme production [63], for lignin degradation [62,63] for the application of biologically pretreated material in the process of biogas production [55]. It is also used in commercial processes in various industries, such as the production of fermented foods such as tempeh [8] and the production of various enzymes [64]. This is due to its simple design and ease of use [65].

The advantages of SSF over submerged fermentation $(\mathrm{SmF})$ are its similarity to the natural habitat of microorganisms, higher productivity, lower cost (due to the use of cheap agro-industrial residues as substrates), lower water consumption, lower use of chemicals, lower generation of waste streams, and lower energy consumption [60,66-68]. Despite these advantages, there are some important technological concerns that need to be considered in order to improve the overall SSF process. Some of them are problems caused by the heterogeneity of the system, such as heat and mass transfer resistance; separation of the microorganisms from the substrate; and sampling problems during fermentation for continuous monitoring of the chemical composition of the substrate and/or product accumulation [69].

The most important factors that have effect on the efficiency of SSF process are substrate (chemical composition, humidity, and particle size), inoculum (concentration, age, and morphology), external carbon and/or nitrogen addition, addition of a specific enzyme's inducers for microorganism's growth and/or desired metabolite production, mixing, temperature, $\mathrm{pH}$, and oxygen concentration.

The basic information of substrates and microorganisms that are commonly used in SSF are provided further in this paper.

\subsection{Substrates Used in SSF}

The choice of substrate is usually determined by its cost and availability, its chemical composition (Tables 1 and 2), and its suitability to be converted into a particular product via biochemical pathways. Depending on the objective (production of the desired enzyme, production of the desired phenolic compounds, organic acids or other valuable product, use for biofuel production, use for feed processing), it is important to know the chemical composition of the substrate and to select a suitable microorganism. If the substrate does not contain the required amounts of nutrients, some macro- and micronutrients are added for optimal growth of the microorganisms [70,71]. Macronutrients (carbon, nitrogen, oxygen, hydrogen, sulfur, phosphorus, $\mathrm{Mg}^{2+}$, and $\mathrm{K}^{+}$) are needed in concentrations greater than $10^{-4} \mathrm{M}$, whereas carbon in the growth medium is the main source of energy. Microelements $\left(\mathrm{Mo}^{2+}, \mathrm{Zn}^{2+}, \mathrm{Cu}^{2+}, \mathrm{Mn}^{2+}, \mathrm{Ca}^{2+}, \mathrm{Na}^{+}\right)$and vitamins, growth hormones, and metabolic precursors are needed in concentration less than $10^{-4} \mathrm{M}$ [60]. AFIRs are a source of carbon, nitrogen, and nutrients and can therefore serve as solid carriers suitable for nutrient absorption and biomass growth [71]. Sometimes it is necessary to combine several different residues according to their chemical composition and to use such a mixture as a substrate to ensure sufficient nutrients for the optimal growth of microorganisms [11]. For SSF, the moisture content of the substrate is one of the most important operating parameters that affects the whole fermentation process. If the moisture content is too high, the interstitial spaces of the solid material will be filled with water and gas diffusion will be restricted. On the other hand, if the moisture content is too low, the growth of microorganisms will be impaired. The optimum moisture content depends on the substrate and the microorganism and changes during the fermentation process [72]. The final water content is the sum of the 
initial water content and the water produced by the metabolism of the microorganisms minus the water removed by evaporation. Water partially evaporates, and at the same time it is produced by the metabolism of the microorganisms [73]. If the production of metabolic water is greater than the evaporated water, then the water content is reduced [62].

Particle size and shape of the substrate can affect the accessibility of nutrients to the microorganism. Smaller particle size causes the smaller inter-particle spaces and the greater pressure drops when air flows through the substrate mass. The particles with a larger surface area tend to be contiguous with the flat surfaces and thus actually exclude oxygen, limiting the growth of microorganisms [74]. The particle size range of the substrate used in SSF is usually between 0.25 and $7.5 \mathrm{~mm}$, depending on the type of substrate used [75-79].

\subsection{Microorganisms Used in SSF}

Filamentous fungi, yeasts, and bacteria can be used in the SSF process to produce value-added compounds. Unicellular organisms such as bacteria and yeast grow as a biofilm, while multicellular filamentous organisms grow in the form of a mycelium, which is comprised of aerial and penetrative hyphae. If the layer of hyphae is thick, then water moves by capillary action from the substrate, resulting with layer into a moist biofilm. A biofilm can also be formed in the case when the bed is mixed, since mixing causes squashing of aerial hyphae onto the surface of the substrate [8]. The most commonly used microorganisms in SSF are filamentous fungi. The choice of microorganism depends on the desired end product, while the choice of substrate is an important parameter for the successful growth of the selected microorganism [80]. The microorganisms can be used as single cultures, as identifiable mixed cultures, or as a consortium of mixed indigenous microorganisms. Many factors can affect the growth of microorganisms, such as the moisture content and properties of the substrate (chemical composition, particle size, height of the substrate layer), temperature, aeration, mixing, initial concentration, and age of the microorganisms $[80,81]$. Microbial growth usually results in the release of metabolic heat. High temperatures can lead to denaturation of enzymes and affect metabolite production. Since SSF occurs in the absence of free water, it is difficult to dissipate the heat generated during microbial growth due to the limited thermal conductivity of the solid substrate and the low heat capacity of the air. The difficulties in controlling the temperature in SSF can become even more pronounced when the process is carried out on a large scale.

\subsubsection{Filamentous Fungi}

Filamentous fungi comprise almost the entire kingdom of fungi and represent the most diverse group of microorganisms that produce filamentous hyphae. SSFs mimic the natural habitats of filamentous fungi and grow on the surface of and within substrate parts due to their hyphal growth. The term filamentous fungi is used in contrast to yeasts, which are essentially unicellular fungi [8]. Filamentous fungi have great potential for the production of enzymes with high commercial value and/or many different valuable compounds by SSF as a result of enzymatic activity (Table 3) $[5,11,80]$.

There are numerous studies on the cultivation of filamentous fungi of the genus Trametes under SSF conditions on different AFIRs for the purpose of laccase production. For example, when comparing the cultivation of T. hirsuta on grape seeds in two types of laboratory-scale bioreactors (immersion and tray bioreactors), one study found the tray bioreactor to be better in terms of the highest laccase activity achieved $\left(2.5 \times 10^{5}\right.$ $3 \times 10^{5}$ nkat/L) [59]. Studies by Bucić-Kojić et al. [82] have shown that T. versicolor, in addition to laccase production, is also effective in the recovery of phenolic acids during SSF on corn silage in laboratory jars. Thanks to the complex enzyme system of T. versicolor, which successfully degrades lignin, there was an increase in the extraction yield of phenolic acids (syringic acid, vanillic acid, $p$-hydroxybenzoic acid, caffeic acid) during the biological treatment compared to the initial biologically untreated corn silage.

Filamentous fungi of the genera Aspergillus and Rhizopus are commonly used in studies investigating the SSF process because they produce several enzymes with broad substrate 
specificity that are stable at lower $\mathrm{pH}$ and high temperatures and play an important role in the hydrolysis of phenolic conjugates [83]. Dulf et al. [83] investigated the cultivation of $A$. niger and $R$. oligosporus on apricot pomaces under SSF conditions. The obtained results showed that there is an increase in total phenolic content when $R$. oligosporus was used until the ninth day of fermentation, and in the case of $A$. niger until the sixth day of fermentation. They also concluded that SSF with filamentous fungi contributes to a greater recovery of lipids from apricot kernels and obtains oil with a high content of linoleic acid.

Table 3. Filamentous fungi used for the production of enzymes and other value-added products during SSF on different food industry waste or by-products.

\begin{tabular}{|c|c|c|c|c|}
\hline Division & Microorganisms & Substrates & Products & Reference \\
\hline \multirow{10}{*}{ Basidiomycota } & Trametes versicolor & tomato pomace & laccase, xylanase, protease & [84] \\
\hline & Trametes versicolor & brewer spent grain & laccase, polyphenols & [55] \\
\hline & Trametes versicolor & corn silage & $\begin{array}{c}\text { laccase, manganese peroxidase, } \\
\text { caffeic acid, vanillic acid, } \\
\text { p-hydroxybenzoic acid, } \\
\text { syringic acid }\end{array}$ & [82] \\
\hline & Trametes versicolor & barley husk and egg shell & laccase & [85] \\
\hline & Trametes pubescens & banana skin & laccase & [75] \\
\hline & Trametes hirsuta & grape seeds & laccase & [59] \\
\hline & $\begin{array}{l}\text { Phanerochaete } \\
\text { chrysosporium }\end{array}$ & apple pomace & phenolic antioxidants & [86] \\
\hline & Pleurotus ostreatus & $\begin{array}{l}\text { potato peel, wheat bran, } \\
\text { tomato pomace, fresh } \\
\text { pineapple residue, rice straw }\end{array}$ & $\begin{array}{l}\text { ligninolytic enzymes, xylanase, } \\
\text { protease, bioactive phenolic, } \\
\text { antioxidant compound }\end{array}$ & {$[84,87-89]$} \\
\hline & Pleurotus ostreatus & $\begin{array}{c}\text { apple bagasse, } \\
\text { agave mezcalero bagasse }\end{array}$ & $\begin{array}{l}\text { phenolic compounds, } \\
\text { flavonoids, triterpenes }\end{array}$ & {$[90]$} \\
\hline & Bjerkandera adusta & wheat bran & $\begin{array}{l}\text { carboxymethil cellulase, } \\
\text { manganese peroxidase, } \\
\text { laccase, xylanase }\end{array}$ & [87] \\
\hline \multirow{9}{*}{ Ascomycota } & Aspergillus niger & plum fruit by-products & $\begin{array}{c}\text { higher lipid } \\
\text { recovery, isoquercitrin }\end{array}$ & [76] \\
\hline & Aspergillus niger & apricot pomace & $\begin{array}{l}\text { neochlorogenic and chlorogenic } \\
\text { acids, rutin, } \\
\text { quercetine-3(6"acetyl-glucoside) }\end{array}$ & [83] \\
\hline & Aspergillus niger & $\begin{array}{l}\text { granadilla seeds flour, } \\
\text { moringa leaves }\end{array}$ & phenolic compounds & {$[91,92]$} \\
\hline & Aspergillus niger & sugar molasses & gluconic acid & [93] \\
\hline & $\begin{array}{c}\text { Aspergillus niger } \\
\text { Aspergillus ibericus }\end{array}$ & olive pomace, winery waste & bioactive compounds & [11] \\
\hline & $\begin{array}{l}\text { Aspergillus niger } \\
\text { Rhizopus oligosporus }\end{array}$ & chokeberry pomace & cinnamic acid, flavonols & [57] \\
\hline & Ceratocystis fimbriata & coffee husk & fruit flavor & [94] \\
\hline & $\begin{array}{l}\text { Thermoascus } \\
\text { aurantiacus }\end{array}$ & $\begin{array}{c}\text { orange, sugarcane bagasse, } \\
\text { wheat bran }\end{array}$ & pectinases & [95] \\
\hline & $\begin{array}{l}\text { Thermomyces } \\
\text { lanuginosus }\end{array}$ & $\begin{array}{l}\text { hull-less pumpkin } \\
\text { oil pomace }\end{array}$ & lipase & [96] \\
\hline
\end{tabular}


Table 3. Cont.

\begin{tabular}{|c|c|c|c|c|}
\hline Division & Microorganisms & Substrates & Products & Reference \\
\hline \multirow{5}{*}{ Zygomycota } & Rhizophus oligosporus & plum fruit by-products & $\begin{array}{l}\text { higher lipid recovery, } \\
\text { isoquercitrin }\end{array}$ & {$[76]$} \\
\hline & Rhizophus oligosporus & apricot pomace & $\begin{array}{l}\text { neochlorogenic and chlorogenic } \\
\text { acids, rutin, } \\
\text { quercetine-3(6"acetyl-glucoside) }\end{array}$ & {$[83]$} \\
\hline & $\begin{array}{l}\text { Actinomucor elegans } \\
\text { Umbelopsis isabellina }\end{array}$ & grape pomace & $\gamma$-linolenic acid and carotenoids & {$[12]$} \\
\hline & Rhizopus delemar F2 & apple pomace & carbohydrase production & [97] \\
\hline & Mortierella alpina & oilseed cakes & $\begin{array}{l}\text { increased nutritional value of } \\
\text { oilseed cakes }\end{array}$ & {$[56]$} \\
\hline
\end{tabular}

\subsubsection{Other Microorganisms}

Besides filamentous fungi, yeasts and bacteria are also used in SSF. Filamentous fungi are more resistant to bacterial contamination, and yeasts and some types of bacteria have the ability to thrive when grown in low water activity environments. Actinomycetes such as Streptomyces sp. are resistant to extreme conditions and can colonize the substrate abundantly; thus, they are also used in SSF $[98,99]$.

Bacteria are mostly used for enzyme production (various proteases, amylase, exopolygalacturonase, mannanase, tannase, xylanase, lipase, etc.), and yeasts are known for the production of clorogenic acid, aromatics, etanol, etc. For example, Bacillus sp. BBXS-2 was used to produce protease and amylase in non-sterile open SSF. Wheat straw proved to be the best of several substrates used (sugarcane bagasse, wheat straw, rice straw, and rice husks). The activity of protease was about 12,200 U/g dry matter and amylase $6900 \mathrm{U} / \mathrm{g}$ dry matter after 5 days of fermentation. Produced enzymes were used as an additive to detergent, which increased its efficiency in removing starchy stains up to 2.5 times [100]. Kluyveromyces marxianus is a yeast that belongs to the GRAS (generally regarded as safe) group of microorganisms and is considered a microorganism that can grow on a variety of substrates and under extreme conditions. Therefore, it is frequently used in bioprocesses such as SSF [78,101]. Medeiros et al. [101] cultivated K. marxianus on five different substrates (apple pomace, cassava bagasse, sugarcane bagasse, sunflower seed bran, and giant palm bran) under SSF conditions to produce aroma compounds. Cassava bagasse and palm bran were found to be the best substrates for yeast growth, and the components produced in the highest amounts were ethyl acetate, ethanol, and acetaldehyde.

Data on the utilization of various AFIRs and their products after solid-state cultivation of bacteria (Table 4) and yeasts (Table 5) are reviewed in this paper.

Table 4. Bacteria used in SSF for production of different compounds.

\begin{tabular}{cccc}
\hline Microorganisms & Substrates & Products & Reference \\
\hline Actinobacillus succinogenes & fruit and vegetable hydrolysate & succinic acid & xylanase, laccase \\
\hline Bacillus halodurans FNP 135 & wheat bran & mannanase, protease & [103] \\
\hline Bacillus nealsoni PN-11 & wheat bran & protease, amylase & [104] \\
\hline Bacillus subtilis BBXS-2 & $\begin{array}{c}\text { sugarcane bagasse, wheat straw, rice } \\
\text { straw, rice husk }\end{array}$ & alkaline protease \\
\hline Bacillus subtilis DM-04 & $\begin{array}{c}\text { potato peels, mustered oil cake, wheat } \\
\text { bran, rice bran, banana leaves, } \\
\text { tea leaves }\end{array}$ & [100] & [105] \\
\hline Bacillus subtilis RCK & wheat bran & [106] &
\end{tabular}


Table 4. Cont.

\begin{tabular}{|c|c|c|c|}
\hline Microorganisms & Substrates & Products & Reference \\
\hline Bacillus thuringiensis & $\begin{array}{l}\text { municipal solid waste mixed with } \\
\text { wood chips }\end{array}$ & $\begin{array}{l}\text { compost with enhanced } \\
\text { biopesticide properties }\end{array}$ & [107] \\
\hline $\begin{array}{c}\text { Brevibacterium casei MSA19 } \\
\text { Serratia rubidaea SNAU02 } \\
\text { Nocardiopsis lucentensis MSA04 }\end{array}$ & $\begin{array}{l}\text { oil seed cake, wheat bran, tannery } \\
\text { treated sludge, tannery pretreated } \\
\text { sludge, treated molasses and pretreated } \\
\text { molasses, groundnut oil cake, coconut } \\
\text { oil cake, gingelly oil cake, castor } \\
\text { oilcake, palm oil cake, sunflower oil } \\
\text { cake and mahua oil cake }\end{array}$ & biosurfactants & [108-110] \\
\hline Clostridium phytofermentans & switchgrass & $\begin{array}{l}\text { reducing sugars that are further } \\
\text { metabolized to ethanol and acetate }\end{array}$ & [68] \\
\hline Cupriavidus necator & soy cake, babassu cake & $\begin{array}{c}\text { biodegradable polymers } \\
\text { (polyhydroxyalkanoates, PHAs) }\end{array}$ & {$[111,112]$} \\
\hline Enterococcus faecalis M2 & wheat bran & $\begin{array}{c}\text { improved antioxidant properties } \\
\text { and nutritional quality of } \\
\text { wheat bran }\end{array}$ & [58] \\
\hline Lactobacillus amylophillus GV6 & wheat bran & L-(+)-lactic acid & [113] \\
\hline $\begin{array}{l}\text { Lactobacillus casei } \\
\text { Lactobacillus fermentum }\end{array}$ & broken dried chestnuts & improved nutritional composition & [114] \\
\hline Lactobacillus sp. ASR-S1 & $\begin{array}{l}\text { tamarind seed powder, wheat bran, } \\
\text { palm kernel cake, coffee husk }\end{array}$ & tannase & [115] \\
\hline Pseudomonas sp. BUP6 & $\begin{array}{l}\text { deoiled cake of groundnut, gingelly, } \\
\text { coconut, soybean and cotton seed }\end{array}$ & lipase & [116] \\
\hline $\begin{array}{l}\text { Streptococcus thermophiles } \\
\text { Lactobacillus bulgaricus }\end{array}$ & wheat bran & $\begin{array}{l}\text { improved nutritional, physical and } \\
\text { flavor properties of wheat bran }\end{array}$ & {$[77]$} \\
\hline Streptomyces sp. & $\begin{array}{l}\text { cassava residues, rapeseed cake, } \\
\text { mushroom residues, bean cake, wheat } \\
\text { bran, rice bran, wheat straw }\end{array}$ & $\begin{array}{l}\text { biolubricant oleogels, } \varepsilon \text {-poly-lysine } \\
\text { (food preservative) }\end{array}$ & {$[117,118]$} \\
\hline Streptomyces sp. & soybean meal ground, wheat bran & L-asparaginase & [119] \\
\hline Streptomyces sp. MDG147 & wheat straw & biolubricant oleogels & [118] \\
\hline
\end{tabular}

Table 5. Yeasts used in SSF for production of different compounds.

\begin{tabular}{|c|c|c|c|}
\hline Microorganisms & Substrates & Products & Reference \\
\hline $\begin{array}{l}\text { Active dry yeast (commercial baker's } \\
\text { yeast with high sugar tolerance) }\end{array}$ & wheat bran & $\begin{array}{l}\text { improve the nutritional, physical } \\
\text { and flavor properties of wheat bran }\end{array}$ & [77] \\
\hline $\begin{array}{c}\text { Kluyveromyces marxianus ATCC } 10022 \\
\text { Pichia kudriavzevii }\end{array}$ & sugarcane bagasse & $\begin{array}{l}\text { 2-phenylethanol, } \\
\text { 2-phenethyl acetate }\end{array}$ & {$[120,121]$} \\
\hline Kluyveromyces marxianus & $\begin{array}{l}\text { sugarcane bagasse, sugar beet } \\
\text { molasses, cassava bagasse, giant } \\
\text { palm bran }\end{array}$ & aroma compounds & {$[78,101]$} \\
\hline Kluyveromyces marxianus NRRLY-7571 & $\begin{array}{l}\text { sugarcane bagasse, corn steep } \\
\text { liquor, soybean meal, } \\
\text { sugarcane molasses }\end{array}$ & inulinase & [122] \\
\hline Monascus purpureus & $\begin{array}{l}\text { corn meal, peanut meal, coconut } \\
\text { residue and soybean meal }\end{array}$ & red pigment & [123] \\
\hline $\begin{array}{c}\text { Meyerozyma guilliermondii } \\
\text { Candida glaebosa } \\
\text { Cryptococcus victoriae } \\
\text { Leucosporidium scotti }\end{array}$ & $\begin{array}{l}\text { inert support of polyurethane and } \\
\text { addition of nutrient medium }\end{array}$ & L-asparaginase, protease & [124] \\
\hline
\end{tabular}


Table 5. Cont.

\begin{tabular}{|c|c|c|c|}
\hline Microorganisms & Substrates & Products & Reference \\
\hline $\begin{array}{c}\text { Pichia pastoris } \\
\text { Kluyveromyces marxianus } \\
\text { Kluyveromyces lactis } \\
\text { Saccharomyces cerevisiae } \\
\text { Candida sp. } \\
\text { Aureobasidium pulluans } \\
\text { Cryptococcus aureus } \\
\text { Schwanniomyces castellii } \\
\text { Endomicopsis burtonii }\end{array}$ & $\begin{array}{l}\text { polyurethane foam, apple } \\
\text { pomace, cassava bagasse, } \\
\text { sugarcane bagasse, sunflower } \\
\text { seeds, giant palm, corn grits, } \\
\text { wheat bran, soy bran, soy peel, } \\
\text { corn cob }\end{array}$ & proteins and secondary metabolites & [81] \\
\hline Saccharomyces cerevisiae & coffee pulp & chlorogenic acid & [125] \\
\hline Saccharomyces cerevisiae & corn cob residues & ethanol & [126] \\
\hline Saccharomyces cerevisiae PM-16 & $\begin{array}{l}\text { grape pomace, fresh fruit and } \\
\text { vegetable residues, corn cob } \\
\text { residues }\end{array}$ & ethanol & [126-128] \\
\hline $\begin{array}{l}\text { Saccharomyces cerevisiae } \\
\text { Schwanniomyces occidentalis } \\
\text { Scheffersomyces stipitis }\end{array}$ & fresh fruit and vegetable residues & ethanol & [127] \\
\hline Yarrowia lipolytica & $\begin{array}{c}\text { luffa sponge, okara, dried loofah } \\
\text { sponge, wheat bran, corncob, } \\
\text { buckwheat husk, } \\
\text { sugarcane bagasse }\end{array}$ & $\gamma$-decalactones, erythritol & {$[79,129]$} \\
\hline Zygosaccharomyces rouxii & oatmeal and wheat bran & glutaminase & [130] \\
\hline
\end{tabular}

\section{Enzyme Production by SSF}

During the biotransformation process of AFIRs for the purpose of producing various value-added products, biofuels, or animal feeds, the conversion of lignocellulosic biomass into fermentable sugars, sugar acids, and/or phenols is carried out by a complex enzymatic system of selected microorganisms [131].

SSF can offer significant benefits in the economic aspects of the enzyme production compared to SmF, since it uses low-cost and easily available substrates, such as lignocellulosic substrates, especially AFIRs [132]. Selection of substrate, microorganism, and process conditions has influence on desired enzyme(s) production. This section describes the catalytic activities of the most investigated enzymes produced by SSF by different microorganisms, and possible industrial application are given.

\subsection{Lignocellulolytic Enzymes}

Lignin is a complex, aromatic, and optically inert hydrophobic amorphous threedimensional polymer consisting mainly of three different phenylpropane alcohols: $p$ coumaryl, coniferyl, and sinapyl. Their quantities depend on various factors, such as plant species, maturity, and the space localization in the cell [20]. Lignin is responsible for the structural rigidity of plants, their impermeability, and their resistance to microbial attacks and oxidative stress. Due to its properties, lignin is a major obstacle in the AFIR bioconversion process into valuable compounds [18]. The enzymatic system responsible for the fungal degradation of lignin is comprised of ligninases: phenol oxidases (laccase, EC 1.10.3.2) and peroxidases (manganese peroxidase (MnP), EC 1.11.1.13, lignin peroxidase (LiP), EC 1.11.1.7) [133].

Laccases are multi-copper glycoproteins that use molecular oxygen to oxidize various aromatic and non-aromatic compounds by a radical-catalyzed reaction mechanism. Laccase can be used in food and beverage industries for modification of color appearance, in the pulp and paper industry for delignification, and in the textile industry for textile bleaching or dye synthesis, as well as for many other purposes such as soil bioremediation, herbicide 
degradation, synthetic chemistry, cosmetics, and biosensors [134,135]. Laccases are found in higher plants, insects, prokaryotes, and fungi, but the most commonly used microorganisms in SSF for laccase production are white-rot fungi such as T. versicolor, T. pubescens, Ganoderma lucidum, and Pleurotus eryngii. Osma et al. [75] showed that banana peels can be a good substrate for the cultivation of T. pubescens under SSF conditions for laccase production. They indicated that by using this type of non-expensive substrates, it is possible to produce enzymes with higher activities at lower production costs. Produced laccase had a maximum activity of $1500 \mathrm{U} / \mathrm{L}$ and was found to be more efficient in decolorization of anthraquinone dyes compared to commercial laccase. Potato peel waste, pretreated with distilled water, is also one of the examples of economical substrates for the production of highly active laccase (6708.3 U/L) under SSF conditions with P. ostreatus [88].

Manganese peroxidase $(\mathrm{MnP})$ belongs to the peroxidase family. It is an extracellular glycosylated heme enzyme that use $\mathrm{H}_{2} \mathrm{O}_{2}$ to oxidize $\mathrm{Mn}^{\mathrm{II}}$ to $\mathrm{Mn}^{\mathrm{III}}$-chelate. This enzyme is mostly produced by numerous species of fungi (Basidiomycetes), especially white-rot fungi, and bacteria (Actinomycetes). It belongs to group of enzymes that have a significant role in efficient bioconversion of plant residues. $\mathrm{MnP}$ finds its use in various industries-paper, food, dye, textile, cosmetics, and many others [88].

Lignin peroxidase ( $\mathrm{LiP})$ is a water-soluble glycosylated enzyme that also uses $\mathrm{H}_{2} \mathrm{O}_{2}$ for catalysis. LiP is enzyme capable of producing radical cations through one-electron oxidation of nonphenolic aromatic compounds as well as phenolic aromatic compounds such as veratryl alcohol or 1,4-dimethoxybenzene [136]. This enzyme, like MnP, is produced mostly by filamentous fungi and participates in lignin degradation, having many applications in different industries $[88,134]$. The white-rot fungus Inonotus obliquus produces all three of the above ligninolytic enzymes (laccase, MnP, and Lip) under SSF conditions. $\mathrm{Xu}$ et al. [137] optimized process parameters such as $\mathrm{pH}$, temperature, substrate moisture ratio, and inoculum level. Various lignocellulosic materials have been used as substrates (wheat bran, wheat straw, rice straw, peanut shell, sugarcane bagasse, cassava peel, birch branch, beech branch). Under optimal conditions, laccase, MnP, and LiP enzyme activities of $81.94 \pm 7.55,1603 \pm 7.76$, and $1500 \pm 21.44 \mathrm{IU} / \mathrm{g}$ were obtained, respectively.

\subsection{Cellulolytic Enzymes}

Cellulose is an unbranched long polymer of $\beta$-D-glucose units linked by $(1 \rightarrow 4)$ glycosidic bonds to form cellobiose-repeating units in the cellulose chain. A numerous hydroxyl groups SSF can offer significant benefits on the inner and outer surface of cellulose-forming hydrogen bonds, while cellulose chains are interlinked by hydrogen bonds and Van der Waals forces. Owing to different orientations throughout the structure, cellulose molecules have different levels of crystallinity-low crystallinity (amorphous regions) and high crystallinity (crystalline regions) [20].

Cellulases are enzymes that have the ability to break cellulose and convert it into simple sugars. They include endoglucanases (1,4- $\beta$-D-glucan glucohydrolase), exoglucanases or cellobiohydrolases (1,4- $\beta$-D-glucan cellobiohydrolase), and $\beta$-glucosidases or cellobiases ( $\beta$-D-glucoside glucohydrolase). Endoglucanases (EC 3.2.1.4) randomly hydrolyze internal glycosidic linkages ( $\beta-1,4$ glucosidic bonds), resulting in shorter polymer chains and an increase of released number of reducing ends.

Endoglucanases find their application in the formulation of detergent compositions for increasing the production yield. They can also be used for improving the nutritive quality of products obtained in different food industry sectors (fruit processing industry; beer, oil, and bakery industries). They are known to be used in feed production [138] and in the textile and pharmaceutical industries as well [19].

Endoglucanases are mainly produced by fungi and bacteria cultivated on AFIRs. The most important producers of endoglucanases are given in Table 6. Exoglucanases (EC 3.2.1.91) or cellobiohydrolases (CBHs) catalyze cellulose hydrolysis to cellobiose units by acting on reducing and non-reducing end of the cellulose. Furthermore, released cellobiose units can be converted to glucose by $\beta$-glucosidase [139]. CBHs have tunnel-shaped 
active sites that accept only a substrate chain via its end terminal regions. It works by stinging the cellulose chain through the tunnel, removing the cellobiose units in a sequential manner [140]. The most important producers of exoglucanases are given in Table 6.

$\beta$-Glucosidases (EC 3.2.1.21) catalyze the hydrolysis of the $\beta$-glucosidic linkages, $\beta$-linked oligosaccharides, and oligosaccharides with the release of glucose. They reduce cellobiose-mediated repression and thus enable cellulolytic enzymes to be more effective [139]. Due to its ability of utilizing different glycosidic substrates, $\beta$-glucosidase is also an industrially important enzyme. It can be used for enzymatic hydrolysis of cellulose for different purposes: production of fermentable sugars, coproduction of functional foods, production of low-viscosity gellan foods, and improvement of food and beverage quality. The result of hydrolytic activity of $\beta$-glucosidase is the releasing of aglycone moiety, which has strong biological activity and can be used as antitumor agents in the prevention of coronary heart disease and cancer. Namely, the most of phenolic compounds from AFIRs exist in conjugated form with sugars linked to hydroxyl groups. This conjugation in the form of glucosides reduces their antioxidant potential since the availability of free hydroxyl groups on the phenol ring affects the resonance stabilization of free radicals. The reduced antioxidant activity has a direct impact on the weaker health functionality during the ingestion of these compounds in the body [141]. It has been recognized that bioaccessibility of high-molecular weight polyphenols (e.g., hydrolysable, condensed tannins), complex flavonoids conjugated with sugars and acetylated with hydroxycinnamic acids, are lower compared to aglycones (units without sugar) and low-molecular weight polyphenols [142]. Therefore, liberation of free phenolic compounds may improve their effect on the health functionality. The most important producers of $\beta$-glucosidases are given in Table 6 . In addition to ligninolytic enzymes, the previously mentioned white-rot fungus I. obliquus also produces cellulolytic enzymes under SSF conditions. The maximum activities of the enzymes carboxymethylcellulase, filter paper cellulase, and $\beta$-glucosidase obtained under optimal process conditions using wheat bran as substrate at $40 \%$ inoculum, $\mathrm{pH} 6.0$, and substrate/moisture ratio of $1: 2.5$ were $27.15,3.16$, and $2.53 \mathrm{IU} / \mathrm{g}$, respectively [137].

Trichoderma is one of the microorganisms that have been extensively studied for the production of various industrially important enzymes, mainly cellulase, exoglucanase, and $\beta$-glucosidase under SSF conditions using different AFIRs as substrates. The studies conducted by Shazhadi et al. [143] aimed at hyperproduction of exoglucanase and $\beta$ glucosidase using a low-cost and readily available corn stover substrate. Optimization of process conditions (substrate amount $15 \mathrm{~g} ; 50 \% \mathrm{w} / \mathrm{w}$ moisture, $6 \mathrm{~mL}$ inoculum, $\mathrm{pH}$ $6.0,35^{\circ} \mathrm{C}$ ) for successful growth of co-culture of T. viride and G. lucidum on corn stover resulted in production of exoglucanase and $\beta$-glucosidase enzymes and their activities of $485 \pm 6.5 \mathrm{U} / \mathrm{mL}$ and $255 \pm 3.3 \mathrm{U} / \mathrm{mL}$ after 5 days of incubation, respectively. They also investigated the influence of additional carbon and nitrogen sources regulating enzyme synthesis during growth of white-rot fungi, and the combination of glucose and ammonium sulfate proved to be the best in the production of exoglucanase and $\beta$-glucosidase.

\subsection{Hemicellulolytic Enzymes}

Hemicellulose is a complex of polysaccharide matrixes composed of different units of sugars (xylans, glucans, xyloglucans, callose, mannans, and glucomannans). It is the second most abundant polysaccharide in plant cell wall. Xylan is the most abundant hemicellulose polymer, constituting around $70 \%$ of hemicelluloses. Galcto(gluco)mannans and xyloglucans are another two major hemicelluloses in plant cell wall. In order to degrade such a complex material, microorganisms should have ability to produce a large set of hemicellulases, which act in interaction. 
Table 6. Valorization of different AFIRs for the production of enzymes from different microorganisms.

\begin{tabular}{|c|c|c|c|c|}
\hline & zymes & Microorganism & Substrate & Reference \\
\hline \multirow{7}{*}{ Lignolytic } & \multirow{6}{*}{ laccase } & Trametes versicolor & $\begin{array}{c}\text { corn silage, brewers' spent grain, } \\
\text { barley husk }\end{array}$ & {$[82,85,144]$} \\
\hline & & Trametes pubescens & banana skin & [75] \\
\hline & & Pleurotus eryngii & peach waste & [145] \\
\hline & & Aspergillus flavus PUF5 & dried ridge gourd peel & [146] \\
\hline & & Ganoderma lucidum & wheat bran & [147] \\
\hline & & Lysinibacillus sp. & wheat bran & [148] \\
\hline & $\begin{array}{l}\text { manganese peroxidase } \\
\text { lignin peroxidase }\end{array}$ & Inonotus obliquus & $\begin{array}{c}\text { birch branch, beech branch, rice } \\
\text { straw, wheat straw, wheat bran, } \\
\text { sugarcane bagasse, cassava peel, } \\
\text { peanut shell }\end{array}$ & [137] \\
\hline \multirow{10}{*}{ Cellulolytic } & \multirow{6}{*}{$\begin{array}{l}\text { cellulase } \\
\text { endoglucanase } \\
\text { exoglucanase }\end{array}$} & Trichoderma sp. & corn cob, wheat bran & [149] \\
\hline & & Penicillium roqueforti & rice husk & [150] \\
\hline & & Aspergilus fumigatus & wheat straw & [151] \\
\hline & & Thermoascus aurantiacus & Jatropha deoiled seed cake & [138] \\
\hline & & Aspergillus fumigatus & wheat straw & [152] \\
\hline & & $\begin{array}{l}\text { Trichoderma viride } \\
\text { Ganoderma lucidum }\end{array}$ & corn stover & [143] \\
\hline & cellobiase & Humicola insolens & $\begin{array}{c}\text { paddy straw, soybean pod husk, } \\
\text { sugarcane bagasse, groundnut } \\
\text { shells, corn stalks and pigeonpea } \\
\text { pod husk }\end{array}$ & [153] \\
\hline & \multirow{3}{*}{$\beta$-glucosidase } & Lichtheimia ramosa & $\begin{array}{l}\text { wheat bran, soy bran, corn cob, } \\
\text { corn straw, rice peel, sugar cane } \\
\text { bagasse }\end{array}$ & [154] \\
\hline & & $\begin{array}{l}\text { Thermoascus aurantiacus } \\
\text { Aureobasidium pullulans }\end{array}$ & $\begin{array}{l}\text { wheat bran, soy bran, soy peel, } \\
\text { corn cob, corn straw }\end{array}$ & [155] \\
\hline & & $\begin{array}{l}\text { Trichoderma viride } \\
\text { Ganoderma lucidum }\end{array}$ & corn stover & [143] \\
\hline \multirow{7}{*}{ Hemicellulolytic } & \multirow{7}{*}{ xylanase } & Aspergillus oryzae & wheat bran & [72] \\
\hline & & Aspergillus tubingensis & wheat straw, sorghum straw & [156] \\
\hline & & $\begin{array}{l}\text { Bacillus } \\
\text { stearothermophilus }\end{array}$ & wheat bran & [157] \\
\hline & & Aspergillus niger & rice straw & [158] \\
\hline & & Aspergillus awamori & tomato pomace & [159] \\
\hline & & $\begin{array}{l}\text { Thermomyces } \\
\text { lanuginosus }\end{array}$ & wheat bran & [160] \\
\hline & & Humicola insolens & $\begin{array}{c}\text { paddy straw, soybean pod husk, } \\
\text { sugarcane bagasse, groundnut } \\
\text { shells, corn stalks and pigeonpea } \\
\text { pod husk }\end{array}$ & [153] \\
\hline
\end{tabular}

Hemicellulases include xylanases (EC 3.2.1.8), $\beta$-mannanases (EC 3.2.1.78), arabinofuranosidases (EC 3.2.1.55), and $\beta$-xylosidases (EC 3.2.1.37). Endo-1,4- $\beta$-xylanases (also called xylanases, endoxylanases, 1,4-D-xylan-xylanohydrolases, endo-1,4- $\beta$-D-xylanases, $\beta-1,4-$ xylanases, and $\beta$-xylanases) belong to the glycosil hydrolase family. They catalyze the hydrolysis of 1,4-glycosidic linkages between xylose residues in the backbone of xylans [161]. 
Since xylan is the major part of hemicellulose, xylanase is the key enzyme for depolymerization of hemicellulose components [72,162]. For complete hydrolysis of xylan to be achieved, the following enzymes are required: $\alpha$-arabinofuranosidase, $\alpha$-glucuronidase, acetylxylan esterase, and hydroxycinnamic acid esterase split side residues from the xylan backbone. Xylanases find their application in the food industry (brewing, wine production, juice clarification, baking), textile industry, and bioremediation $[157,158,161]$. Additionally, they can be applied in the pulp and paper industry, which results in a reduced amount of chlorine and chlorine dioxide commonly used for bleaching paper pulp. The most important producers of xylanases are given in Table 6.

Tomato pomace is a waste available in large quantities, and its chemical composition contains proteins, lipids, carbohydrates, amino acids, carotenoids, and minerals. UmszaGuez et al. [159] used this waste as a substrate in SSF for xylanase production. Fermentation was carried out in a conical flask and a laboratory scale plate-type SSF reactor by A. awamori. In conical flasks, the maximum activity of xylanase was reached between the fourth and eighth day of fermentation (about $100 \mathrm{IU} / \mathrm{g}_{\mathrm{ds}}$ ), while in the plate-type SSF reactor, the maximum activity was reached on the fifth day of fermentation $\left(195.92 \pm 11.0 \mathrm{IU} / \mathrm{g}_{\mathrm{ds}}\right)$.

Some studies have shown that co-cultivation of compatible microorganisms can enhance enzyme biosynthesis. Gupta et al. [103] studied the co-cultivation of SSF bacteria (Bacillus sp. and B. halodurans FNP135) producing xylanase and laccase. They used wheat bran as substrate. Under optimized conditions ( $\mathrm{pH} 10.5$, inoculum size $10+10 \%$, moisture/substrate ratio 0.8:1), a significant increase in the production of xylanase (1685 IU/g) and laccase $(2270 \mathrm{IU} / \mathrm{g})$ was obtained. The mixed enzyme preparation was found to be effective in bio-bleaching of craft pulp.

Some researchers are concerned with the purification and characterization of the enzymes produced, as this is an important step that provides insight into enzyme properties and helps determine potential applications. David et al. [104] optimized the production of mannanase and protease using Bacillus nealsonii under SSF conditions on wheat bran as substrate. The protease was purified by standard protein purification procedures that include methods such as ammonium sulfate precipitation, gel filtration chromatography, and ion exchange chromatography. Each step was performed at $4{ }^{\circ} \mathrm{C}$, and enzyme volume, protease activity, and protein content were determined after each step. The combination of mannanase and protease from $B$. nealsonii was found to be effective in removing various stains when used as detergent additive.

\section{Production of Phenolic Compounds and Other Value-Added Compounds}

AFIRs are rich in nutrients and bioactive compounds. Therefore, these residues have potential applications in SSF processes for the obtainment of beneficial compounds such as phenolic compounds, organic acids, flavor, and aroma compounds (Tables 3-5), which possess antioxidative, anti-inflammatory, antiallergic, antiviral, anticancer, antimicrobial, and antimutagenic properties [2]. A trend is to enrich food products with AFIRs, primarily because of the high content of dietary fibers and bioactive polyphenolic compounds, which increase the nutritional value and help in diseases prevention, but also positively affect stability, organoleptic properties, and technological properties of the final product [163].

Phenolic compounds represent the important group of bioactive compounds from plant material. They are the most abundant antioxidants in the human diet. Their structure consists of an aromatic ring, containing one or more hydroxyl substituents. The number and position of the hydroxyl groups, and the nature of substituents on the aromatic rings, affect the physiological properties of phenolic compounds. These compounds show a broad spectrum of physiological properties, such as anti-allergenic, anti-artherogenic, antiinflammatory, anti-microbial, antioxidant, anti-thrombotic, cardioprotective, and vasodilatory effects [164]. Generally, they can be divided into three main groups, namely, phenolic acids (hydroxycinnamic acids, hydroxybenzoic acids), flavonoids (flavones, flavonols, flavanols, anthocyanins), and tannins (hydrolysable and nonhydrolyzable or condensed tannins) [165]. AFIRs are a cheap and rich source of potentially functional ingredients, such 
as phenolic compounds, thus promoting a circular economy concept. For example, after the processing of apples, it is estimated that $82-99 \%$ of the original polyphenols remain in apple pomace [166].

Lignin fraction of AFIRs contains various phenolic compounds, mainly phenolic acids such as ferulic, $p$-coumaric, syringic, vanillic, and $p$-hydroxybenzoic [39]. Simple phenolic compounds from biological materials can usually be isolated by extraction with organic solvents, while non-extractable highly polymerized proanthocyanidins and phenol complexes with proteins, fibers, and polysaccharides have to be hydrolyzed or degraded beforehand. The methods used for this are acid hydrolysis, which is environmentally unacceptable, and enzymatic hydrolysis, which is economically inconvenient [82]. On the other hand, phenolic compounds can be recovered by SSF, during which the microorganisms synthesize enzymes involved in breakdown of complex lignocellulosic material and release of these valuable compounds [11] (Table 7).

Table 7. Production of phenolic compounds from some food industry residues by SSF.

\begin{tabular}{|c|c|c|c|}
\hline Products & Conditions & Remarks & Reference \\
\hline $\begin{array}{l}\text { Total polyphenolic } \\
\text { compounds from } \\
\text { apple pomace }\end{array}$ & $\begin{array}{l}\text { Substrate: apple pomace, treated with inducers: } \\
\text { copper sulphate }(2 \mathrm{mM}) \text {, veratryl alcohol }(2 \mathrm{mM}) \\
\text { and Tween- } 80(0.1 \%) ; \mathrm{pH} 4.5 ; \text { autoclaved }\left(121^{\circ} \mathrm{C} \text {, }\right. \\
30 \text { min), moisture content } 72 \% \mathrm{w} / v \text {. } \\
\text { Microorganism: } \text { P. chrysosporium, inoculation } \\
\text { with spore suspension }\left(2.5 \times 10^{6} \text { spores } / \mathrm{g}\right. \\
\text { of solid). } \\
\text { SSF: carried out in flasks, in controlled } \\
\text { environment at } 37 \pm 1{ }^{\circ} \mathrm{C} \text { for } 14 \text { days. } \\
\text { Extraction (optimization): } \\
\text { - } \quad \text { type: UAE (in ultrasonication bath, or } \\
\quad \text { MAE (in sealed green chem Teflon reactor } \\
\quad \text { vessel, pressure of } 692 \mathrm{kPa} \text {, power } 400 \mathrm{~W}) \text {. } \\
\quad \text { solvent: water, or } 60 \%, 70 \%, \text { or } 80 \% \\
\quad \text { ethanol; acetone; or methanol. } \\
\quad \text { temperature: } 30,40,50,60,70, \text { or } 80{ }^{\circ} \mathrm{C} \text {. } \\
\text { interval: } 20,30, \text { or } 40 \text { min (UAE); } 5,10, \text { or } \\
\quad 15 \text { min (MAE). } \\
\quad \text { effect of surfactant: different } \\
\quad \text { concentrations of Tween- } 20(0.1 \%, 1 \%, 2 \% \text {, } \\
\text { and } 5 \% \text { in } v / v \text { with water). } \\
\text { After the extraction, sample mixture was } \\
\text { centrifuged at } 9268 \times g \text { for } 20 \text { min to obtain the } \\
\text { supernatant for further determination of total } \\
\text { phenolic content (at } 725 \mathrm{~nm}) \text { and free radical } \\
\text { scavenging activity (DPPH method at } 517 \mathrm{~nm}) \text {. }\end{array}$ & $\begin{array}{l}\text { The phenol content was } \\
\text { higher in the fermented apple } \\
\text { pomace, and the antioxidant } \\
\text { activity correlated with the } \\
\text { increase in polyphenol } \\
\text { content, with both values } \\
\text { depending on the type of } \\
\text { solvent, extraction } \\
\text { temperature, extraction time, } \\
\text { and method used. }\end{array}$ & [86] \\
\hline
\end{tabular}

Substrate: corn silage, particle size $1.0-2.0 \mathrm{~cm}$; autoclaved $\left(121^{\circ} \mathrm{C}, 20 \mathrm{~min}\right)$.

Microorganism: T. versicolor TV-6, cultivated on PDA medium for 7 days at $27^{\circ} \mathrm{C}$; five mycelial plugs (diameter $1 \mathrm{~cm}$ ) suspended in $10 \mathrm{~cm}^{3}$ of sterile water (inoculum).

Individual polyphenolic compound from grape pomace
SSF: performed in laboratory jars at $27^{\circ} \mathrm{C}$ for 5 , 9,13 , and 20 days.

Extraction: milled dry substrate after SSF was extracted by $50 \%$ ethanol with solid/liquid ratio $1: 40$, in a shaking-water bath at $80^{\circ} \mathrm{C}$ by (200 rpm) for $120 \mathrm{~min}$.

After the extraction, samples were centrifuged for $10 \mathrm{~min}$ at $10,000 \times g$ in order to obtain liquid extracts for further UHPLC analysis of phenolic acids.
After 20 days of corn silage treatment with $T$. versicolor, 10.4-, 3.4-, 3.0-, and 1.8-fold increments in extraction yield of syringic acid, vanillic acid, $p$-hydroxybenzoic acid, and caffeic acid, respectively, were reached. 
Table 7. Cont.

\begin{tabular}{|c|c|c|c|}
\hline Products & Conditions & Remarks & Reference \\
\hline $\begin{array}{l}\text { Phenolic antioxidants from } \\
\text { grape waste }\end{array}$ & $\begin{array}{l}\text { Substrate: grape waste, dehydrated at } \\
60{ }^{\circ} \mathrm{C} / 24 \mathrm{~h} \text {, pulverized ( } 30 \text {-mesh), stored at } 22{ }^{\circ} \mathrm{C} \text {. } \\
\text { Microorganism: different fungal strains: A. niger } \\
\text { GH1, PSH, Aa-20, ESH; Penicillium pinophilum } \\
\text { ESH2, ESH3; Penicillium purpurogenum } \mathrm{GH} 2 \text {; } \\
\text { inoculation with } 2 \times 10^{7} \text { fungal spores per gram } \\
\text { of solid support. } \\
\text { SSF: performed in tray reactor at } 30{ }^{\circ} \mathrm{C} / 60 \mathrm{~h} \text {. } \\
\text { Assay: total antioxidant activity of the extracts } \\
\text { was tested by two different free radical (DPPH. } \\
\text { and ABTS·+) inhibitions; free gallic acid content } \\
\text { was estimated by HPLC. }\end{array}$ & $\begin{array}{l}\text { The extracts of grape waste } \\
\text { enhanced their free radical } \\
\text { scavenging and preserved the } \\
\text { capacity to avoid the lipid } \\
\text { peroxidation after SSF. } \\
\text { Gallic acid is not the only } \\
\text { phenolic compound related to } \\
\text { the free radical scavenging } \\
\text { and antioxidant properties of } \\
\text { the fermented samples. }\end{array}$ & [167] \\
\hline $\begin{array}{l}\text { Phenolic antioxidants from } \\
\text { pomegranate peels }\end{array}$ & $\begin{array}{l}\text { Substrate: pomegranate peels, cleaned, dried at } \\
60^{\circ} \mathrm{C} / 48 \mathrm{~h} \text {, pulverized, stored at room } \\
\text { temperature in black bags. } \\
\text { Microorganism: } A \text {. niger } \mathrm{GH} 1 \text {; inoculation with } \\
2 \times 10^{7} \text { spores / } \mathrm{g} \text { of plant material, or substrate } \\
\text { impregnated with culture broth. } \\
\text { SSF: carried out in flasks at } 30^{\circ} \mathrm{C} \text { for } 96 \mathrm{~h} \text {. } \\
\text { Assay: tannins were analyzed using a } \\
\text { spectrophometric method; concentration of gallic } \\
\text { and ellagic acids was determined by HPLC. }\end{array}$ & $\begin{array}{l}\text { The ellagic acid was } \\
\text { accumulated considerably in } \\
\text { pomegranate peels after } \\
\text { fungal fermentation, which } \\
\text { demonstrated that the high } \\
\text { level of hydrolysable tannins } \\
\text { in pomegrante peel tannins } \\
\text { are mainly ellagitannins. }\end{array}$ & [168] \\
\hline
\end{tabular}

Substrate: chokeberry (cultivar "Nero") pomace, dried $<40{ }^{\circ} \mathrm{C}$, ground $(0.5-1 \mathrm{~mm})$, stored at $18{ }^{\circ} \mathrm{C}$; moisturized $(65 \%)$ with a nutrient solution (containing yeast extract and glucose), $\mathrm{pH}$ 5.5; autoclaved at $121^{\circ} \mathrm{C} / 30 \mathrm{~min}$.

Microorganism: A. niger ATCC-6275 and $R$. oligosporus ATCC-22959; inoculating cultures were produced by growing the strains on fresh PDA at $27^{\circ} \mathrm{C}$ for 10 days, and spore inoculum was prepared by washing the agar surface with sterile distilled water.

Phenolic antioxidants from chokeberry pomace
SSF: was carried out in in Erlenmeyer flasks at $30{ }^{\circ} \mathrm{C}$ for 12 days; substrate was inoculated with spore suspension $2 \times 10^{7}$ spores/g of solid. Extraction: in an ultrasonic bath for $30 \mathrm{~min}$ at $40{ }^{\circ} \mathrm{C}$ with solvent mixture (hydrochloric acid methanol: water in the ratio 1: 80: 19).

The mixtures were centrifuged $(4000 \times g$ for $10 \mathrm{~min}$ ); supernatants were filtered and evaporated under vacuum and then stored in methanol $\left(4{ }^{\circ} \mathrm{C}\right)$ until analysis (total phenolics, flavonoids, and anthocyanins; individual phenolics; antioxidant activities).
The extractable phenolics increased more than 1.7-fold during both fermentation processes, and a similar trend was observed for total flavonoids. The free radical scavenging ability of phenolic extracts were significantly enhanced during the SSFs. The amounts of flavonols and cinnamic acids increased while the concentrations of glycosylated anthocyanins decreased substantially. 
Table 7. Cont.

\begin{tabular}{|c|c|c|c|}
\hline Products & Conditions & Remarks & Reference \\
\hline $\begin{array}{l}\text { Water-soluble phenolic } \\
\text { antioxidants } \\
\text { from cranberry pomace }\end{array}$ & $\begin{array}{l}\text { Substrate: freshly pressed cranberry pomace, } \\
\text { vacuum-dried and stored in a refrigerator. } \\
\text { Microorganism: Lentinus edodes was maintained } \\
\text { on PDA slants and Petri plates at } 4{ }^{\circ} \mathrm{C} \text { and } \\
\text { sub-cultured. The fungus was resuscitated by } \\
\text { transferring onto a PDA plate and cultured at } \\
\text { room temperature } 20 \text { days before use. } \\
\text { SSF: carried out in in Erlenmeyer flasks at } 28^{\circ} \mathrm{C} \\
\text { for } 25 \text { days (cranberry pomace + calcium } \\
\text { carbonate + water + ammonium nitrate or fish } \\
\text { protein hydrolysate was autoclaved at } 121^{\circ} \mathrm{C} \text { for } \\
20 \text { min and the vegetative mycelia from one PDA } \\
\text { plate were inoculated into flasks). } \\
\text { Extraction: distilled water or } 95 \% \text { ethanol was } \\
\text { added to fungus-pomace flask and the culture } \\
\text { was homogenized for } 1 \text { min and then centrifuged } \\
\text { at } 15,000 \times g \text { at } 4{ }^{\circ} \mathrm{C} \text { for } 20 \text { min and then filtered. }\end{array}$ & $\begin{array}{l}\text { There was an increase in the } \\
\text { extractable phenolic content. } \\
\text { Both phenolics and } \\
\text { antioxidant capacity } \\
\text { correlated with the increase in } \\
\text { the } \beta \text {-glucosidase activity, } \\
\text { showing that the enzyme may } \\
\text { play an important role in the } \\
\text { release of phenolic aglycones } \\
\text { from cranberry pomace and, } \\
\text { therefore, increase the } \\
\text { antioxidant capacity. }\end{array}$ & [141] \\
\hline
\end{tabular}

UAE-ultrasonic-assisted extraction; MAE-microwave-assisted extraction; PDA-potato dextrose agar; DPPH-1,1-diphenyl-2picrylhydrazyl radical; ABTS-+-2,2'-azino-bis(3-ethylbenzothiazoline-6-sulfonic acid) radical; UHPLC—ultra-high-performance liquid chromatography; HPLC—-high-performance liquid chromatography.

Ajila et al. [86] studied the ability of P. chrysosporium to release phenolic antioxidants from apple pomace using SSF and examined the effectiveness of various extraction parameters on antioxidant extraction (Table 7). They concluded that the SSF improved not only the nutraceutical properties of apple pomace but also the antioxidant activity wherein the increase in these values is dependent on the extraction conditions. The $\mathrm{IC}_{50}$ values obtained from the polyphenol extract by optimum extraction conditions (microwave-assisted extraction at $40{ }^{\circ} \mathrm{C}$ for $30 \mathrm{~min}$ with $80 \%$ acetone) was $20.12 \mu \mathrm{g}_{\mathrm{db}}$ of sample for apple pomace and $12.24 \mu \mathrm{g}_{\mathrm{db}}$ of sample for fermented apple pomace. Bucić-Kojić et al. [82] investigated the recovery of phenolic acid and enzyme production from biologically treated corn silage by white-rot fungus T. versicolor. According to obtained results, increments in extraction yield of caffeic acid, vanillic acid, $p$-hydroxybenzoic acid, and syringic acid were observed in fermented grape pomace (Table 7). Further, Martínez-Ávila et al. [167] reported that the cultivation of Aspergillus and Penicillium strains on grape waste in SSF can improve the production of phenolic antioxidant compound (gallic acid). Pomegranate peel and creosote bush leaves were successfully used as a substrate for ellagic and gallic acid production by $A$. niger GH1 [168]. In the recent period, large-scale chokeberry cultivation has increased due to its high polyphenolic content and antioxidant activity. SSF of the chokeberry pomace by $A$. niger and $R$. oligosporus and its influence on the content of phenolic compounds, antioxidant activity, and lipid composition were investigated by Dulf et al. [57]. They concluded that SSF leads to an increase of total phenolic and total flavonoid contents, as well as a formation of lipids with better nutritional quality characteristics. On the same substrate, SSF with Lentinus edodes resulted in an increase in the ellagic acid content [141].

Organic acids are used as preservatives in food and beverage production since they can prevent spoilage and prolong the shelf life of food. Sharma et al. [93] have shown feasibility of SSF gluconic acid production from sugarcane molasses by A. niger ARNU-4 using tea waste as substrate.

In the research conducted by Nimnoi and Lumyong [123], fungus M. purpureus was cultivated on corn meal, peanut meal, and coconut residue and soybean meal for the purpose of red pigment production.

Fungi and bacteria have been reported as microorganisms with great ability to produce flavor and aroma compounds during SSF. Production of fruity flavors by fungi Ceratocystis fimbriata under SSF conditions, using a coffee husk as a substrate, was tested by Soares et al. [94]. Kluyveromyces marxianus proved to be suitable for producing value-added 
aroma compounds by SSF using a sugarcane bagasse and sugar beet molasses [78]. Application of SSF for the production of biosurfactants, biolubricant oleogels, and biodegradable polymers (PHAs) has been shown to be effective using certain species of bacteria $[110,112,118]$.

\section{Biofuel Production}

Due to the increasing trend towards the production of biofuels as a substitute for fossil fuels, environmentally friendly methods for their production are being developed. The firstgeneration biofuels are usually produced from crops (sugar cane, sugar beet, wheat, rice, sunflower oil, etc.), but from a sustainability point of view, the main limitation of production of first-generation biofuels is food and energy competition [169]. Therefore, there is a large amount of interest in the development and use of second- and third-generation biofuels in agriculture, forestry, and industrial production, as well as in advanced sustainable waste management. The second-generation biofuels are mainly directed towards the production of biofuels from reusable materials such as municipal solid waste, agro-industrial waste, and sewage sludge, which can actually produce biofuels such as bioethanol, biodiesel, bioalcohols, biogas, and biohydrogen [9,169].

Complex chemical structure of biomass (e.g., AFIRs) requires the pretreatment of such lignocellulosic material, which is a pivotal step before being involved in the hydrolysis and fermentation process. Delignification and detoxification are two main targets of ligninolytic enzymes in biofuel production. Delignification presents reduction of lignin content in biomass, while detoxification means reduction of toxic components present in biomass hydrolysate [9]. Tišma et al. [55] investigated the effect of pretreatment of corn silage in biogas productivity. Corn silage pretreated with white-rot fungus T. versicolor increase biogas productivity. Jain et al. [68] found that bioprocessing of switchgrass under SSF conditions by $C$. phytofermentans may represent an alternative to $\mathrm{SmF}$ in the production of reducing sugars that are metabolized to ethanol and acetate. Clostridium phytofermentans is considered a suitable anaerobic mesophilic bacterium for biological treatment of lignocellulosic biomass because it produces numerous enzymes that participate in degradation of complex carbohydrates to simple sugars.

\section{Feed Production}

The quality of feed is an imperative of modern livestock agriculture. There is a great increase of need for feed as a consequence of world population growth and the need for food of animal origin.

Therefore, many researchers focus on manipulation with unconventional feed sources, such as lignocellulosic biomass with microorganisms. AFIRs remaining after cereal (e.g., corn, barley, wheat, and rye) processing possess binding properties because of starch they contain. However, due to the low nitrogen and mineral content, as well as the reduced digestibility associated with high lignin, cellulose, and hemicellulose content, direct utilization of AFIRs for ruminant feeding is limited [170]. To improve the access of microbial hydrolytic enzymes to cellulose and hemicellulose for digestibility enhancement, one must break lignin carbohydrate linkages in the plant cell wall. SSF could bring benefits in terms of enhancement of digestibility of those types of materials, but this bioprocess has not yet fully developed and much effort is still needed for production animal feed by SSF on a large scale. White-rot fungi such as Phanerochaete chrysosporium, Pleurotus sp., L. edodes, Coriolus versicolor, Phlebia sp., Ceriporiopsis subvermispora, and Ganoderma sp. have been applied for SSF of various AFIRs (wheat straw, olive mill solid waste, madake bamboo, tanniniferous lespedeza plants, oil palm fronds etc.) to produce animal feed of better quality through improved digestibility, enhanced palatability, and availability of fermentable energy to ruminal microbes [170]. The cultivation of different microorganisms on AFIRs has great potential in the production of biomass suitable for use as animal feed supplement, since such dry biomass may contain 30-60\% protein, up to $40 \%$ carbohydrate, and $20-50 \%$ oil [171]. The composition of dry biomass depends on cultivation method (submerged or solid-state fermentation), growing conditions, choice of microorganism, and 
type of organic substrate [171]. In addition to microbial proteins or single-cell proteins, various enzymes that can be used as a supplement in animal feed can be manufactured by SSF. Enzymes such as xylanases, pectinases, and amylases are used in animal feed primarily to increase nutrient digestibility. Cellulases, which stimulate fiber degradation, and tannins, which hydrolyze tannins, are also used. Studies have shown that in ruminants, lower concentrations of tannins in the diet result in increased nitrogen assimilation, which in turn leads to higher growth rates and increased milk production. The enzyme phytase is also important for improving the nutritional value of animal feed, as its mechanism releases phosphorus, which is an important nutrient for proper animal development [172].

The problems in modern livestock agriculture are that animal feed and feed materials can be contaminated with undesirable substances (e.g., heavy metals, mycotoxins), which may originate from the environment and/or the production process. When production animals consume such contaminated feed, the contaminants may transfer to food of animal origin, such as liver, meat, and milk. In the European Union (and most of the rest of the world), legislation is in place to manage the feed and feed material contamination. Official limits and guidelines indicate safe levels of each contaminant, often per feed (material) group. Moreover, procedures for control of the presence of the contaminant are prescribed, e.g., the number of samples to be taken for which contaminants. Within the European Union (EU), Regulation (EC) No. 882/2004 provides rules for the official controls that have to be performed to ensure the verification of compliance with feed and food law, animal health, and animal welfare rules [173].

The possible solution to remove mycotoxins is the use of selected white-rot fungi, such as, e.g., $T$. versicolor culture filtrate, which was shown to be a very promising tool for aflatoxin B1 reduction of contaminated maize in animal feed. Studies on the use of $T$. versicolor in the animal nutrition indicate its highly relevance in the term of sustainable feed production [69].

\section{Conclusions and Future Prospects}

AFIRs are rich natural sources of various nutrients and bioactive compounds. Although these residues can cause serious economic and environmental problems due to unacceptable disposal, large quantities of residues are considered as potential for reuse and as energy sources. Their availability and low cost could lead to more economical industrial scale processes. SSF is an environmentally friendly bioprocess that does not use expensive AFIRs as substrates and can offer significant advantages in economic terms for the production of valuable compounds (enzymes, polyphenolic compounds, biofuels, enriched animal feed, etc.). It is also an alternative to the pretreatment process for the low-cost production of sustainable biofuels, which poses a challenge for the commercialization of the production process. The main drawback of this technology is that the hydrolysis of lignocellulosic components in some feedstocks is too slow, which prevents this method as a potential pretreatment method at industrial level. To speed up the process and make it more efficient, it is possible to use a combination of another pretreatment method (physical, chemical) with the biological pretreatment. However, the development and establishment of combined methods still requires a large amount of research and work to reach full efficiency. Numerous studies have led to great progress in the development of SSF processes from laboratory scale to scale-up and bioreactor application. With the increasing competition in the industry, optimization of the process and bioreactor design are important factors in the field of future research.

Author Contributions: A.B.-K. conceived the review article and provided advice to enhance the quality of the manuscript. G.Š., M.P. and M.T. collected of related materials, and designed and drafted manuscript. D.K.K. and S.T. were involved in critical review of the manuscript. All authors have read and agreed to the published version of the manuscript.

Funding: This work was supported by the Croatian Science Foundation under the project (IP-201801-1227) “Development of a sustainable integrated process for the production of bioactive isolates 
from food industry residues" (POPI-WinCEco) and by the European regional development fund (ERDF) under the project (KK.01.1.1.04.0107) “Bioconversion of lignocellulosic materials to value added feed" (Bio4Feed).

Data Availability Statement: The data presented in this study are available on request from the corresponding author.

Conflicts of Interest: The authors declare no conflict of interest. The funders had no role in the design of the study; in the collection, analyses, or interpretation of data; or in the writing of the manuscript.

\section{References}

1. EUR-Lex-52007DC0059—EN_EUR-Lex. Available online: https://eur-lex.europa.eu/legal-content/EN/TXT/?uri=celex: 52007DC0059 (accessed on 14 March 2021).

2. Teixeira, A.; Baenas, N.; Dominguez-Perles, R.; Barros, A.; Rosa, E.; Moreno, D.A.; Garcia-Viguera, C. Natural Bioactive Compounds from Winery By-Products as Health Promoters: A Review. Int. J. Mol. Sci. 2014, 15, 15638-15678. [CrossRef]

3. Călinoiu, L.F.; Cătoi, A.-F.; Vodnar, D.C. Solid-State Yeast Fermented Wheat and Oat Bran as A Route for Delivery of Antioxidants. Antioxidants 2019, 8, 372. [CrossRef]

4. Sharma, S.K.; Bansal, S.; Mangal, M.; Dixit, A.K.; Gupta, R.K.; Mangal, A.K. Utilization of Food Processing By-Products as Dietary, Functional, and Novel Fiber: A Review. Crit. Rev. Food Sci. Nutr. 2016, 56, 1647-1661. [CrossRef] [PubMed]

5. Mussatto, S.I.; Ballesteros, L.F.; Martins, S.; Teixeira, J.A. Use of Agro-Industrial Wastes in Solid-State Fermentation Processes. Ind. Waste 2012, 274. [CrossRef]

6. Kumar, K.; Yadav, A.N.; Kumar, V.; Vyas, P.; Dhaliwal, H.S. Food Waste: A Potential Bioresource for Extraction of Nutraceuticals and Bioactive Compounds. Bioresour. Bioprocess. 2017, 4, 18. [CrossRef]

7. Allikian, K.; Edgar, R.; Syed, R.; Zhang, S. Fundamentals of Fermentation Media. In Essentials in Fermentation Technology; Berenjian, A., Ed.; Learning Materials in Biosciences; Springer International Publishing: Cham, Switzerland, 2019; pp. 41-84, ISBN 978-3-030-16230-6.

8. Mitchell, D.A.; Krieger, N. Solid-State Cultivation Bioreactors. In Essentials in Fermentation Technology; Berenjian, A., Ed.; Learning Materials in Biosciences; Springer International Publishing: Cham, Switzerland, 2019; pp. 105-133, ISBN 978-3-030-16230-6.

9. Plácido, J.; Capareda, S. Ligninolytic Enzymes: A Biotechnological Alternative for Bioethanol Production. Bioresour. Bioprocess. 2015, 2, 23. [CrossRef]

10. Hildén, K.; Mäkelä, M.R. Role of Fungi in Wood Decay. In Reference Module in Life Sciences; Roitberg, B.D., Ed.; Elsevier: Amsterdam, The Netherlands, 2018; Volume 2018, ISBN 978-0-12-809633-8.

11. Filipe, D.; Fernandes, H.; Castro, C.; Peres, H.; Oliva-Teles, A.; Belo, I.; Salgado, J.M. Improved Lignocellulolytic Enzyme Production and Antioxidant Extraction Using Solid-State Fermentation of Olive Pomace Mixed with Winery Waste. Biofuels Bioprod. Biorefining-Biofpr 2020, 14, 78-91. [CrossRef]

12. Dulf, F.V.; Vodnar, D.C.; Toşa, M.I.; Dulf, E.-H. Simultaneous Enrichment of Grape Pomace with $\gamma$-Linolenic Acid and Carotenoids by Solid-State Fermentation with Zygomycetes Fungi and Antioxidant Potential of the Bioprocessed Substrates. Food Chem. 2020, 310, 125927. [CrossRef] [PubMed]

13. Sarsaiya, S.; Jain, A.; Kumar Awasthi, S.; Duan, Y.; Kumar Awasthi, M.; Shi, J. Microbial Dynamics for Lignocellulosic Waste Bioconversion and Its Importance with Modern Circular Economy, Challenges and Future Perspectives. Bioresour. Technol. 2019, 291, 121905. [CrossRef]

14. Olivero, G.; Turrini, F.; Vergassola, M.; Boggia, R.; Zunin, P.; Donno, D.; Beccaro, G.L.; Grilli, M.; Pittaluga, A. The 3Rs: Reduction and Refinement through a Multivariate Statistical Analysis Approach in a Behavioural Study to Unveil Anxiolytic Effects of Natural Extracts of Tilia Tomentosa. Biomed. Sci. Eng. 2019, 3. [CrossRef]

15. Pinela, J.; Omarini, A.B.; Stojković, D.; Barros, L.; Postemsky, P.D.; Calhelha, R.C.; Breccia, J.; Fernández-Lahore, M.; Soković, M.; Ferreira, I.C.F.R. Biotransformation of Rice and Sunflower Side-Streams by Dikaryotic and Monokaryotic Strains of Pleurotus Sapidus: Impact on Phenolic Profiles and Bioactive Properties. Food Res. Int. 2020, 132, 109094. [CrossRef] [PubMed]

16. Sadh, P.K.; Duhan, S.; Duhan, J.S. Agro-Industrial Wastes and Their Utilization Using Solid State Fermentation: A Review. Bioresour. Bioprocess. 2018, 5, 1. [CrossRef]

17. Rameshaiah, G.N.; Jagadish Reddy, M.L. Applications of Ligninolytic Enzymes from a White-Rot Fungus Trametes Versicolor. Univers. J. Environ. Res. Technol. 2015, 5, 1-7.

18. Tan, Y.X.; Mok, W.K.; Lee, J.; Kim, J.; Chen, W.N. Solid State Fermentation of Brewers' Spent Grains for Improved Nutritional Profile Using Bacillus Subtilis WX-17. Fermentation 2019, 5, 52. [CrossRef]

19. Tian, M.; Wai, A.; Guha, T.K.; Hausner, G.; Yuan, Q. Production of Endoglucanase and Xylanase Using Food Waste by Solid-State Fermentation. Waste Biomass Valorization 2018, 9, 2391-2398. [CrossRef]

20. Kovačić, D.; Kralik, D.; Rupčić, S.; Jovičić, D.; Spajić, R.; Tišma, M. Soybean Straw, Corn Stover and Sunflower Stalk as Possible Substrates for Biogas Production in Croatia: A Review. Chem. Biochem. Eng. Q. 2017, 31, 187-198. [CrossRef]

21. FAOSTAT. Available online: http://www.fao.org/faostat/en/\#data/QD (accessed on 16 March 2021).

22. Berger, K.; Falck, P.; Linninge, C.; Nilsson, U.; Axling, U.; Grey, C.; Stalbrand, H.; Karlsson, E.N.; Nyman, M.; Holm, C.; et al. Cereal Byproducts Have Prebiotic Potential in Mice Fed a High-Fat Diet. J. Agric. Food Chem. 2014, 62, 8169-8178. [CrossRef] 
23. Kohli, D.; Garg, D.S.; Jana, D.A.K. Thermal and Morphological Properties of Chemically Treated Barley Husk Fiber. Int. J. Res. Mech. Eng. Technol. 2013, 3, 4.

24. Anukam, A.I.; Goso, B.P.; Okoh, O.O.; Mamphweli, S.N. Studies on Characterization of Corn Cob for Application in a Gasification Process for Energy Production. J. Chem. 2017, 2017, 6478389. [CrossRef]

25. Daud, Z.; Mohd Zainuri, M.H.; Angzzas Sari, M.K.; Awang, H.; Aripin, A.M. Analysis the Chemical Composition and Fiber Morphology Structure of Corn Stalk. Aust. J. Basic Appl. Sci. 2013, 7, 401-405.

26. Maj, G.; Krzaczek, P.; Kuranc, A.; Piekarski, W. Energy Properties of Sunflower Seed Husk as Industrial Extrusion Residue. Agric. Eng. 2017, 21, 77-84. [CrossRef]

27. Hassan, F.E.; Osman, S.; Idris, S.; Alfa, M. Influence of Irrigation System on Characteristics of Pulp and Paper Manufactured from Sunflower Stalks. Int. J. Sci. Technol. 2012, 1, 248-252.

28. ElMekawy, A.; Diels, L.; De Wever, H.; Pant, D. Valorization of Cereal Based Biorefinery Byproducts: Reality and Expectations. Environ. Sci. Technol. 2013, 47, 9014-9027. [CrossRef] [PubMed]

29. nee'Nigam, P.S.; Gupta, N.; Anthwal, A. Pre-treatment of Agro-Industrial Residues. In Biotechnology for Agro-Industrial Residues Utilisation: Utilisation of Agro-Residues; nee'Nigam, P.S., Pandey, A., Eds.; Springer: Dordrecht, The Netherlands, 2009; pp. 13-33, ISBN 978-1-4020-9942-7.

30. de Barros, R.D.R.O.; Becarelli, P.; de Oliveira, R.A.; Tognotti, L.; da Silva Bon, E.P. Triticum Spelta Straw Hydrothermal Pretreatment for the Production of Glucose Syrups via Enzymatic Hydrolysis. Biochem. Eng. J. 2019, 151, 107340. [CrossRef]

31. Ezejiofor, T.I.N.; Enebaku, U.E.; Ogueke, C. Waste to Wealth- Value Recovery from Agro-Food Processing Wastes Using Biotechnology: A Review. Br. Biotechnol. J. 2014, 4, 418-481. [CrossRef]

32. Šimić, G.; Lalić, A.; Horvat, D.; Zdunić, Z.; Koceva Komlenić, D.; Bucić-Kojić, A.; Planinić, M.; Tišma, M. Production and Analysis of the Flour from the Hull-Less Barley. J. Food Meas. Charact. 2021. [CrossRef]

33. Belen Diaz, A.; de Ory, I.; Caro, I.; Blandino, A. Enhance Hydrolytic Enzymes Production by Aspergillus Awamori on Supplemented Grape Pomace. Food Bioprod. Process. 2012, 90, 72-78. [CrossRef]

34. Dwyer, K.; Hosseinian, F.; Rod, M. The Market Potential of Grape Waste Alternatives. J. Food Res. 2014, 3, 91. [CrossRef]

35. Yu, J.; Ahmedna, M. Functional Components of Grape Pomace: Their Composition, Biological Properties and Potential Applications. Int. J. Food Sci. Technol. 2013, 48, 221-237. [CrossRef]

36. Planinić, M.; Aliakbarian, B.; Perego, P.; Greganić, K.; Tomas, S.; Bucić-Kojić, A. Influence of Temperature and Drying Time on Extraction Yield of Phenolic Compounds from Grape Pomace Variety “Portogizac”. Chem. Biochem. Eng. Q. 2015, 29, 343-350. [CrossRef]

37. Baray Guerrero, M.R.; Salinas Gutierrez, J.M.; Melendez Zaragoza, M.J.; Lopez Ortiz, A.; Collins-Martinez, V. Optimal Slow Pyrolysis of Apple Pomace Reaction Conditions for the Generation of a Feedstock Gas for Hydrogen Production. Int. J. Hydrog. Energy 2016, 41, 23232-23237. [CrossRef]

38. Kosmala, M.; Kołodziejczyk, K.; Zduńczyk, Z.; Juśkiewicz, J.; Boros, D. Chemical Composition of Natural and Polyphenol-Free Apple Pomace and the Effect of This Dietary Ingredient on Intestinal Fermentation and Serum Lipid Parameters in Rats. J. Agric. Food Chem. 2011, 59, 9177-9185. [CrossRef]

39. Mussatto, S.I.; Dragone, G.; Roberto, I.C. Ferulic and P-Coumaric Acids Extraction by Alkaline Hydrolysis of Brewer's Spent Grain. Ind. Crops Prod. 2007, 25, 231-237. [CrossRef]

40. Muthusamy, N. Chemical Composition of Brewers SSpent Grain-A Review. Int. J. Sci. Environ. Technol. 2014, 3, $2109-2112$.

41. Budžaki, S.; Strelec, I.; Krnić, M.; Alilović, K.; Tišma, M.; Zelić, B. Proximate Analysis of Cold-Press Oil Cakes after Biological Treatment with Trametes Versicolor and Humicola Grisea. Eng. Life Sci. 2018, 18, 924-931. [CrossRef]

42. Manara, P.; Zabaniotou, A.; Vanderghem, C.; Richel, A. Lignin Extraction from Mediterranean Agro-Wastes: Impact of Pretreatment Conditions on Lignin Chemical Structure and Thermal Degradation Behavior. Catal. Today 2014, 223, 25-34. [CrossRef]

43. Zheng, Y.; Lee, C.; Yu, C.; Cheng, Y.-S.; Simmons, C.W.; Zhang, R.; Jenkins, B.M.; VanderGheynst, J.S. Ensilage and Bioconversion of Grape Pomace into Fuel Ethanol. J. Agric. Food Chem. 2012, 60, 11128-11134. [CrossRef] [PubMed]

44. Ducom, G.; Gautier, M.; Pietraccini, M.; Tagutchou, J.-P.; Lebouil, D.; Gourdon, R. Comparative Analyses of Three Olive Mill Solid Residues from Different Countries and Processes for Energy Recovery by Gasification. Renew. Energy 2020, 145, 180-189. [CrossRef]

45. Roig, A.; Cayuela, M.L.; Sanchez-Monedero, M.A. An Overview on Olive Mill Wastes and Their Valorisation Methods. Waste Manag. 2006, 26, 960-969. [CrossRef]

46. Kodali, B.; Pogaku, R. Pretreatment Studies of Rice Bran for the Effective Production of Cellulose. Electron. J. Environ. Agric. Food Chem. 2006, 5, 1253-1264.

47. Kamal-Eldin, A.; Larke, H.N.; Knudsen, K.-E.B.; Lampi, A.-M.; Piironen, V.; Adlercreutz, H.; Katina, K.; Poutanen, K.; Man, P. Physical, Microscopic and Chemical Characterisation of Industrial Rye and Wheat Brans from the Nordic Countries. Food Nutr. Res. 2009, 53. [CrossRef]

48. de Moraes Rocha, G.J.; Nascimento, V.M.; Goncalves, A.R.; Nunes Silva, V.F.; Martin, C. Influence of Mixed Sugarcane Bagasse Samples Evaluated by Elemental and Physical-Chemical Composition. Ind. Crops Prod. 2015, 64, 52-58. [CrossRef]

49. Ahmed, M.H.; Babiker, S.A.; Elnasir, A.; Elseed, M.; Mohammed, A. Effect of Urea-Treatment on Nutritive Value of Sugarcane Bagasse. ARPN J. Sci. Technol. 2013, 3, 839-843. 
50. Cripwell, R.; Favaro, L.; Rose, S.H.; Basaglia, M.; Cagnin, L.; Casella, S.; van Zyl, W. Utilisation of Wheat Bran as a Substrate for Bioethanol Production Using Recombinant Cellulases and Amylolytic Yeast. Appl. Energy 2015, 160, 610-617. [CrossRef]

51. Kajala, I.; Makela, J.; Coda, R.; Shukla, S.; Shi, Q.; Maina, N.H.; Juvonen, R.; Ekholm, P.; Goyal, A.; Tenkanen, M.; et al. Rye Bran as Fermentation Matrix Boosts in Situ Dextran Production by Weissella Confusa Compared to Wheat Bran. Appl. Microbiol. Biotechnol. 2016, 100, 3499-3510. [CrossRef]

52. Onipe, O.O.; Jideani, A.I.O.; Beswa, D. Composition and Functionality of Wheat Bran and Its Application in Some Cereal Food Products. Int. J. Food Sci. Technol. 2015, 50, 2509-2518. [CrossRef]

53. Mitchell, D.A.; Berovic, M.; Krieger, N. Overview of Solid State Bioprocessing. Biotechnol. Annu. Rev. 2002, 8, 183-225. [CrossRef]

54. Ravindran, R.; Hassan, S.S.; Williams, G.A.; Jaiswal, A.K. A Review on Bioconversion of Agro-Industrial Wastes to Industrially Important Enzymes. Bioeng. Basel Switz. 2018, 5, 93. [CrossRef] [PubMed]

55. Tišma, M.; Planinić, M.; Bucić-Kojić, A.; Panjičko, M.; Zupančič, G.D.; Zelić, B. Corn Silage Fungal-Based Solid-State Pretreatment for Enhanced Biogas Production in Anaerobic Co-Digestion with Cow Manure. Bioresour. Technol. 2018, 253, 220-226. [CrossRef] [PubMed]

56. Ferreira, M.; Fernandes, H.; Peres, H.; Oliva-Teles, A.; Belo, I.; Salgado, J.M. Bio-Enrichment of Oilseed Cakes by Mortierella Alpina under Solid-State Fermentation. LWT 2020, 134, 109981. [CrossRef]

57. Dulf, F.V.; Vodnar, D.C.; Dulf, E.-H.; Diaconeasa, Z.; Socaciu, C. Liberation and Recovery of Phenolic Antioxidants and Lipids in Chokeberry (Aronia melanocarpa) Pomace by Solid-State Bioprocessing Using Aspergillus Niger and Rhizopus Oligosporus Strains. LWT 2018, 87, 241-249. [CrossRef]

58. Mao, M.; Wang, P.; Shi, K.; Lu, Z.; Bie, X.; Zhao, H.; Zhang, C.; Lv, F. Effect of Solid State Fermentation by Enterococcus Faecalis M2 on Antioxidant and Nutritional Properties of Wheat Bran. J. Cereal Sci. 2020, 94, 102997. [CrossRef]

59. Rodríguez Couto, S.; López, E.; Sanromán, M.Á. Utilisation of Grape Seeds for Laccase Production in Solid-State Fermentors. J. Food Eng. 2006, 74, 263-267. [CrossRef]

60. Behera, S.S.; Ray, R.C.; Das, U.; Panda, S.K.; Saranraj, P. Microorganisms in Fermentation. In Essentials in Fermentation Technology; Berenjian, A., Ed.; Learning Materials in Biosciences; Springer International Publishing: Cham, Switzerland, 2019; pp. 1-39, ISBN 978-3-030-16230-6.

61. Steudler, S.; Werner, A.; Walther, T. It Is the Mix that Matters: Substrate-Specific Enzyme Production from Filamentous Fungi and Bacteria Through Solid-State Fermentation. In Solid State Fermentation: Research and Industrial Applications; Steudler, S., Werner, A., Cheng, J.J., Eds.; Advances in Biochemical Engineering/Biotechnology; Springer International Publishing: Cham, Switzerland, 2019; pp. 51-81, ISBN 978-3-030-23675-5.

62. Planinić, M.; Zelić, B.; Čubel, I.; Bucić-Kojić, A.; Tišma, M. Corn Forage Biological Pretreatment by Trametes Versicolor in a Tray Bioreactor. Waste Manag. Res. 2016, 34, 802-809. [CrossRef] [PubMed]

63. Mishra, V.; Jana, A.K. Sweet Sorghum Bagasse Pretreatment by Coriolus Versicolor in Mesh Tray Bioreactor for Selective Delignification and Improved Saccharification. Waste Biomass Valorization 2019, 10, 2689-2702. [CrossRef]

64. Pinheiro, V.E.; Michelin, M.; Vici, A.C.; de Almeida, P.Z.; de Moraes Polizeli, M.D. Trametes Versicolor Laccase Production Using Agricultural Wastes: A Comparative Study in Erlenmeyer Flasks, Bioreactor and Tray. Bioprocess Biosyst. Eng. 2020, 43, 507-514. [CrossRef]

65. Thomas, L.; Larroche, C.; Pandey, A. Current Developments in Solid-State Fermentation. Biochem. Eng. J. 2013, 81, 146-161. [CrossRef]

66. Rodriguez Couto, S. Exploitation of Biological Wastes for the Production of Value-Added Products under Solid-State Fermentation Conditions. Biotechnol. J. 2008, 3, 859-870. [CrossRef] [PubMed]

67. Singhania, R.R.; Patel, A.K.; Soccol, C.R.; Pandey, A. Recent Advances in Solid-State Fermentation. Biochem. Eng. J. 2009, 44, 13-18. [CrossRef]

68. Jain, A.; Morlok, C.K.; Henson, J.M. Comparison of Solid-State and Submerged-State Fermentation for the Bioprocessing of Switchgrass to Ethanol and Acetate by Clostridium Phytofermentans. Appl. Microbiol. Biotechnol. 2013, 97, 905-917. [CrossRef]

69. Tišma, M.; Žnidaršić-Plazl, P.; Šelo, G.; Tolj, I.; Šperanda, M.; Bucić-Kojić, A.; Planinić, M. Trametes Versicolor in LignocelluloseBased Bioeconomy: State of the Art, Challenges and Opportunities. Bioresour. Technol. 2021, 124997. [CrossRef] [PubMed]

70. Farinas, C.S. Developments in Solid-State Fermentation for the Production of Biomass-Degrading Enzymes for the Bioenergy Sector. Renew. Sustain. Energy Rev. 2015, 52, 179-188. [CrossRef]

71. Soccol, C.R.; da Costa, E.S.F.; Letti, L.A.J.; Karp, S.G.; Woiciechowski, A.L.; de Souza Vandenberghe, L.P. Recent Developments and Innovations in Solid State Fermentation. Biotechnol. Res. Innov. 2017, 1, 52-71. [CrossRef]

72. Pirota, R.D.; Tonelotto, M.; da Silva Delabona, P.; Fonseca, R.F.; Paixão, D.A.; Baleeiro, F.C.; Neto, V.B.; Farinas, C.S. Enhancing Xylanases Production by a New Amazon Forest Strain of Aspergillus Oryzae Using Solid-State Fermentation under Controlled Operation Conditions. Ind. Crops Prod. 2013, 45, 465-471. [CrossRef]

73. Figueroa-Montero, A.; Esparza-Isunza, T.; Saucedo-Castañeda, G.; Huerta-Ochoa, S.; Gutiérrez-Rojas, M.; Favela-Torres, E. Improvement of Heat Removal in Solid-State Fermentation Tray Bioreactors by Forced Air Convection. J. Chem. Technol. Biotechnol. 2011, 86, 1321-1331. [CrossRef]

74. Mitchell, D.A.; von Meien, O.F.; Luz, L.F.L.; Berovič, M. Substrate, Air, and Thermodynamic Parameters for SSF Bioreactor Models. Solid-State Ferment. Bioreact. Fundam. Des. Oper. 2006, 265-278. [CrossRef] 
75. Osma, J.F.; Toca Herrera, J.L.; Rodríguez Couto, S. Banana Skin: A Novel Waste for Laccase Production by Trametes Pubescens under Solid-State Conditions. Application to Synthetic Dye Decolouration. Dyes Pigments 2007, 75, 32-37. [CrossRef]

76. Dulf, F.V.; Vodnar, D.C.; Socaciu, C. Effects of Solid-State Fermentation with Two Filamentous Fungi on the Total Phenolic Contents, Flavonoids, Antioxidant Activities and Lipid Fractions of Plum Fruit (Prunus domestica L.) by-Products. Food Chem. 2016, 209, 27-36. [CrossRef] [PubMed]

77. Zhao, H.-M.; Guo, X.-N.; Zhu, K.-X. Impact of Solid State Fermentation on Nutritional, Physical and Flavor Properties of Wheat Bran. Food Chem. 2017, 217, 28-36. [CrossRef]

78. Martínez, O.; Sánchez, A.; Font, X.; Barrena, R. Valorization of Sugarcane Bagasse and Sugar Beet Molasses Using Kluyveromyces Marxianus for Producing Value-Added Aroma Compounds via Solid-State Fermentation. J. Clean. Prod. 2017, 158, 8-17. [CrossRef]

79. Liu, X.; Yu, X.; Zhang, T.; Wang, Z.; Xu, J.; Xia, J.; He, A.; Yan, Y.; Xu, J. Novel Two-Stage Solid-State Fermentation for Erythritol Production on Okara-Buckwheat Husk Medium. Bioresour. Technol. 2018, 266, 439-446. [CrossRef]

80. Srivastava, N.; Srivastava, M.; Ramteke, P.W.; Mishra, P.K. Chapter 23-Solid-State Fermentation Strategy for Microbial Metabolites Production: An Overview. In New and Future Developments in Microbial Biotechnology and Bioengineering; Gupta, V.K., Pandey, A., Eds.; Elsevier: Amsterdam, The Netherlands, 2019; pp. 345-354, ISBN 978-0-444-63504-4.

81. López-Pérez, M.; Viniegra-González, G. Production of Protein and Metabolites by Yeast Grown in Solid State Fermentation: Present Status and Perspectives. J. Chem. Technol. Biotechnol. 2016, 91, 1224-1231. [CrossRef]

82. Bucić-Kojić, A.; Šelo, G.; Zelić, B.; Planinić, M.; Tišma, M. Recovery of Phenolic Acid and Enzyme Production from Corn Silage Biologically Treated by Trametes Versicolor. Appl. Biochem. Biotechnol. 2017, 181, 948-960. [CrossRef] [PubMed]

83. Dulf, F.V.; Vodnar, D.C.; Dulf, E.-H.; Pintea, A. Phenolic Compounds, Flavonoids, Lipids and Antioxidant Potential of Apricot (Prunus armeniaca L.) Pomace Fermented by Two Filamentous Fungal Strains in Solid State System. Chem. Cent. J. 2017, 11, 92. [CrossRef] [PubMed]

84. Iandolo, D.; Piscitelli, A.; Sannia, G.; Faraco, V. Enzyme Production by Solid Substrate Fermentation of Pleurotus Ostreatus and Trametes Versicolor on Tomato Pomace. Appl. Biochem. Biotechnol. 2011, 163, 40-51. [CrossRef]

85. Tišma, M.; Šalić, A.; Planinić, M.; Zelić, B.; Potočnik, M.; Šelo, G.; Bucić-Kojić, A. Production, Characterisation and Immobilization of Laccase for an Efficient Aniline-Based Dye Decolourization. J. Water Process Eng. 2020, 36, 101327. [CrossRef]

86. Ajila, C.M.; Brar, S.K.; Verma, M.; Tyagi, R.D.; Valéro, J.R. Solid-State Fermentation of Apple Pomace Using Phanerocheate Chrysosporium—Liberation and Extraction of Phenolic Antioxidants. Food Chem. 2011, 126, 1071-1080. [CrossRef]

87. Elisashvili, V.; Kachlishvili, E.; Tsiklauri, N.; Metreveli, E.; Khardziani, T.; Agathos, S.N. Lignocellulose-Degrading Enzyme Production by White-Rot Basidiomycetes Isolated from the Forests of Georgia. World J. Microbiol. Biotechnol. 2009, 25, 331-339. [CrossRef]

88. Ozcirak Ergun, S.; Ozturk Urek, R. Production of Ligninolytic Enzymes by Solid State Fermentation Using Pleurotus Ostreatus. Ann. Agrar. Sci. 2017, 15, 273-277. [CrossRef]

89. Rashad, M.M.; Abdou, H.M.; Mahmoud, A.E. Production of Some Bioactive Materials by Pleurotus Ostreatus from Pineapple Residues and Rice Straw via Solid State Fermentation. Res. J. Pharm. Biol. Chem. Sci. 2016, 7, 2730-2736.

90. Ibarra-Cantún, D.; Ramos-Cassellis, M.E.; Marín-Castro, M.A.; Castelán-Vega, R.D.C. Secondary Metabolites and Antioxidant Activity of the Solid-State Fermentation in Apple (Pirus malus L.) and Agave Mezcalero (Agave angustifolia H.) Bagasse. J. Fungi 2020, 6, 137. [CrossRef]

91. Santos, T.R.J.; Feitosa, P.R.B.; Gualberto, N.C.; Narain, N.; Santana, L.C.L.A. Improvement of Bioactive Compounds Content in Granadilla (Passiflora ligularis) Seeds after Solid-State Fermentation. Food Sci. Technol. Int. 2020, 1082013220944009. [CrossRef]

92. Feitosa, P.R.B.; Santos, T.R.J.; Gualberto, N.C.; Narain, N.; de Aquino Santana, L.C.L. Solid-State Fermentation with Aspergillus Niger for the Bio-Enrichment of Bioactive Compounds in Moringa Oleifera (Moringa) Leaves. Biocatal. Agric. Biotechnol. 2020, 27, 101709. [CrossRef]

93. Sharma, A.; Vivekanand, V.; Singh, R.P. Solid-State Fermentation for Gluconic Acid Production from Sugarcane Molasses by Aspergillus Niger ARNU-4 Employing Tea Waste as the Novel Solid Support. Bioresour. Technol. 2008, 99, 3444-3450. [CrossRef]

94. Soares, M.; Christen, P.; Pandey, A.; Soccol, C.R. Fruity Flavour Production by Ceratocystis Fimbriata Grown on Coffee Husk in Solid-State Fermentation. Process Biochem. 2000, 35, 857-861. [CrossRef]

95. Martins, E.S.; Silva, D.; Da Silva, R.; Gomes, E. Solid State Production of Thermostable Pectinases from Thermophilic Thermoascus Aurantiacus. Process Biochem. 2002, 37, 949-954. [CrossRef]

96. Šibalić, D.; Šalić, A.; Tušek, A.J.; Sokač, T.; Brekalo, K.; Zelić, B.; Tran, N.N.; Hessel, V.; Tišma, M. Sustainable Production of Lipase from Thermomyces Lanuginosus: Process Optimization and Enzyme Characterization. Ind. Eng. Chem. Res. 2020, 59, 21144-21154. [CrossRef]

97. Pathania, S.; Sharma, N.; Handa, S. Utilization of Horticultural Waste (Apple pomace) for Multiple Carbohydrase Production from Rhizopus Delemar F2 under Solid State Fermentation. J. Genet. Eng. Biotechnol. 2018, 16, 181-189. [CrossRef]

98. Kaaniche, F.; Hamed, A.; Elleuch, L.; Chakchouk-Mtibaa, A.; Smaoui, S.; Karray-Rebai, I.; Koubaa, I.; Arcile, G.; Allouche, N.; Mellouli, L. Purification and Characterization of Seven Bioactive Compounds from the Newly Isolated Streptomyces Cavourensis TN638 Strain via Solid-State Fermentation. Microb. Pathog. 2020, 142, 104106. [CrossRef] [PubMed]

99. Verduzco-Oliva, R.; Gutierrez-Uribe, J.A. Beyond Enzyme Production: Solid State Fermentation (SSF) as an Alternative Approach to Produce Antioxidant Polysaccharides. Sustainability 2020, 12, 495. [CrossRef] 
100. Qureshi, A.S.; Khushk, I.; Ali, C.H.; Chisti, Y.; Ahmad, A.; Majeed, H. Coproduction of Protease and Amylase by Thermophilic Bacillus Sp. BBXS-2 Using Open Solid-State Fermentation of Lignocellulosic Biomass. Biocatal. Agric. Biotechnol. 2016, 8, 146-151. [CrossRef]

101. Medeiros, A.B.; Pandey, A.; Freitas, R.J.; Christen, P.; Soccol, C.R. Optimization of the Production of Aroma Compounds by Kluyveromyces Marxianus in Solid-State Fermentation Using Factorial Design and Response Surface Methodology. Biochem. Eng. J. 2000, 6, 33-39. [CrossRef]

102. Dessie, W.; Zhang, W.; Xin, F.; Dong, W.; Zhang, M.; Ma, J.; Jiang, M. Succinic Acid Production from Fruit and Vegetable Wastes Hydrolyzed by On-Site Enzyme Mixtures through Solid State Fermentation. Bioresour. Technol. 2018, 247, 1177-1180. [CrossRef]

103. Gupta, V.; Garg, S.; Capalash, N.; Gupta, N.; Sharma, P. Production of Thermo-Alkali-Stable Laccase and Xylanase by CoCulturing of Bacillus Sp. and B. Halodurans for Biobleaching of Kraft Pulp and Deinking of Waste Paper. Bioprocess Biosyst. Eng. 2015, 38, 947-956. [CrossRef]

104. David, A.; Singh Chauhan, P.; Kumar, A.; Angural, S.; Kumar, D.; Puri, N.; Gupta, N. Coproduction of Protease and Mannanase from Bacillus Nealsonii PN-11 in Solid State Fermentation and Their Combined Application as Detergent Additives. Int. J. Biol. Macromol. 2018, 108, 1176-1184. [CrossRef] [PubMed]

105. Mukherjee, A.K.; Adhikari, H.; Rai, S.K. Production of Alkaline Protease by a Thermophilic Bacillus Subtilis under Solid-State Fermentation (SSF) Condition Using Imperata Cylindrica Grass and Potato Peel as Low-Cost Medium: Characterization and Application of Enzyme in Detergent Formulation. Biochem. Eng. J. 2008, 39, 353-361. [CrossRef]

106. Gupta, S.; Kapoor, M.; Sharma, K.K.; Nair, L.M.; Kuhad, R.C. Production and Recovery of an Alkaline Exo-Polygalacturonase from Bacillus Subtilis RCK under Solid-State Fermentation Using Statistical Approach. Bioresour. Technol. 2008, 99, 937-945. [CrossRef] [PubMed]

107. Ballardo, C.; Barrena, R.; Artola, A.; Sánchez, A. A Novel Strategy for Producing Compost with Enhanced Biopesticide Properties through Solid-State Fermentation of Biowaste and Inoculation with Bacillus Thuringiensis. Waste Manag. 2017, 70, 53-58. [CrossRef]

108. Kiran, G.S.; Thomas, T.A.; Selvin, J. Production of a New Glycolipid Biosurfactant from Marine Nocardiopsis Lucentensis MSA04 in Solid-State Cultivation. Colloids Surf. B Biointerfaces 2010, 78, 8-16. [CrossRef] [PubMed]

109. Kiran, G.S.; Sabu, A.; Selvin, J. Synthesis of Silver Nanoparticles by Glycolipid Biosurfactant Produced from Marine Brevibacterium Casei MSA19. J. Biotechnol. 2010, 148, 221-225. [CrossRef] [PubMed]

110. Nalini, S.; Parthasarathi, R. Production and Characterization of Rhamnolipids Produced by Serratia Rubidaea SNAU02 under Solid-State Fermentation and Its Application as Biocontrol Agent. Bioresour. Technol. 2014, 173, 231-238. [CrossRef]

111. Castilho, L.R.; Mitchell, D.A.; Freire, D.M.G. Production of Polyhydroxyalkanoates (PHAs) from Waste Materials and by-Products by Submerged and Solid-State Fermentation. Bioresour. Technol. 2009, 100, 5996-6009. [CrossRef]

112. Sindhu, R.; Pandey, A.; Binod, P. Solid-State Fermentation for the Production of Poly(Hydroxyalkanoates). Chem. Biochem. Eng. Q. 2015, 29, 173-181. [CrossRef]

113. Naveena, B.J.; Altaf, M.; Bhadrayya, K.; Madhavendra, S.S.; Reddy, G. Direct Fermentation of Starch to 1(+) Lactic Acid in SSF by Lactobacillus amylophilus GV6 Using Wheat Bran as Support and Substrate: Medium Optimization Using RSM. Process Biochem. 2005, 40, 681-690. [CrossRef]

114. Yang, X.; Zhou, X.; Zhang, M.; Zhang, Z.; Song, L.; Wang, G.; Zhang, J. Metabolism Analysis for Enhanced Nutritional Profile of Chestnuts Subjected to Anerobic Solid-State Fermentation by Probiotic Lactic Acid Bacteria. J. Food Process. Preserv. 2020, 44, e14360. [CrossRef]

115. Sabu, A.; Augur, C.; Swati, C.; Pandey, A. Tannase Production by Lactobacillus Sp. ASR-S1 under Solid-State Fermentation. Process Biochem. 2006, 41, 575-580. [CrossRef]

116. Faisal, P.A.; Hareesh, E.S.; Priji, P.; Unni, K.N.; Sajith, S.; Sreedevi, S.; Josh, M.S.; Benjamin, S. Optimization of Parameters for the Production of Lipase from Pseudomonas Sp. BUP6 by Solid State Fermentation. Adv. Enzyme Res. 2014, 2, 125-133. [CrossRef]

117. Xu, D.; Yao, H.; Xu, Z.; Wang, R.; Xu, Z.; Li, S.; Feng, X.; Liu, Y.; Xu, H. Production of $\varepsilon$-Poly-Lysine by Streptomyces Albulus PD-1 via Solid-State Fermentation. Bioresour. Technol. 2017, 223, 149-156. [CrossRef] [PubMed]

118. Borrero-López, A.M.; Blánquez, A.; Valencia, C.; Hernández, M.; Arias, M.E.; Eugenio, M.E.; Fillat, Ú.; Franco, J.M. Valorization of Soda Lignin from Wheat Straw Solid-State Fermentation: Production of Oleogels. ACS Sustain. Chem. Eng. 2018, 6, 5198-5205. [CrossRef]

119. El-Naggar, N.E.-A.; Moawad, H.; Abdelwahed, N.A.M. Optimization of Fermentation Conditions for Enhancing Extracellular Production of L -Asparaginase, an Anti-Leukemic Agent, by Newly Isolated Streptomyces Brollosae NEAE-115 Using Solid State Fermentation. Ann. Microbiol. 2017, 67, 1-15. [CrossRef]

120. Martínez-Avila, O.; Sánchez, A.; Font, X.; Barrena, R. Fed-Batch and Sequential-Batch Approaches To Enhance the Bioproduction of 2-Phenylethanol and 2-Phenethyl Acetate in Solid-State Fermentation Residue-Based Systems. J. Agric. Food Chem. 2019, 67, 3389-3399. [CrossRef]

121. Martínez-Avila, O.; Sánchez, A.; Font, X.; Barrena, R. 2-Phenylethanol (Rose aroma) Production Potential of an Isolated Pichia Kudriavzevii through Solid-State Fermentation. Process Biochem. 2020, 93, 94-103. [CrossRef]

122. Astolfi, V.; Joris, J.; Verlindo, R.; Oliveira, J.V.; Maugeri, F.; Mazutti, M.A.; de Oliveira, D.; Treichel, H. Operation of a Fixed-Bed Bioreactor in Batch and Fed-Batch Modes for Production of Inulinase by Solid-State Fermentation. Biochem. Eng. J. 2011, 58-59, 39-49. [CrossRef] 
123. Nimnoi, P.; Lumyong, S. Improving Solid-State Fermentation of Monascus Purpureus on Agricultural Products for Pigment Production. Food Bioprocess Technol. 2011, 4, 1384-1390. [CrossRef]

124. Correa, H.T.; Vieira, W.F.; Pinheiro, T.M.A.; Cardoso, V.L.; Silveira, E.; Sette, L.D.; Pessoa, A.; Filho, U.C. L-Asparaginase and Biosurfactants Produced by Extremophile Yeasts from Antarctic Environments. Ind. Biotechnol. 2020, 16, 107-116. [CrossRef]

125. Santos da Silveira, J.; Durand, N.; Lacour, S.; Belleville, M.-P.; Perez, A.; Loiseau, G.; Dornier, M. Solid-State Fermentation as a Sustainable Method for Coffee Pulp Treatment and Production of an Extract Rich in Chlorogenic Acids. Food Bioprod. Process. 2019, 115, 175-184. [CrossRef]

126. Zheng, T.; Yu, H.; Liu, S.; Jiang, J.; Wang, K. Achieving High Ethanol Yield by Co-Feeding Corncob Residues and Tea-Seed Cake at High-Solids Simultaneous Saccharification and Fermentation. Renew. Energy 2020, 145, 858-866. [CrossRef]

127. Estrada-Martínez, R.; Favela-Torres, E.; Soto-Cruz, N.O.; Escalona-Buendía, H.B.; Saucedo-Castañeda, G. A Mild Thermal Pre-Treatment of the Organic Fraction of Municipal Wastes Allows High Ethanol Production by Direct Solid-State Fermentation. Biotechnol. Bioprocess Eng. 2019, 24, 401-412. [CrossRef]

128. Rodríguez, L.A.; Toro, M.E.; Vazquez, F.; Correa-Daneri, M.L.; Gouiric, S.C.; Vallejo, M.D. Bioethanol Production from Grape and Sugar Beet Pomaces by Solid-State Fermentation. Int. J. Hydrog. Energy 2010, 35, 5914-5917. [CrossRef]

129. Try, S.; De-Coninck, J.; Voilley, A.; Chunhieng, T.; Waché, Y. Solid State Fermentation for the Production of $\gamma$-Decalactones by Yarrowia Lipolytica. Process Biochem. 2018, 64, 9-15. [CrossRef]

130. Iyer, P.; Singhal, R.S. Production of Glutaminase (E.C. 3.2.1.5) from Zygosaccharomyces Rouxii in Solid-State Fermentation and Modeling the Growth of Z. Rouxii Therein. J. Microbiol. Biotechnol. 2010, 20, 737-748. [CrossRef]

131. Saroj, P.; Manasa, P.; Narasimhulu, K. Characterization of Thermophilic Fungi Producing Extracellular Lignocellulolytic Enzymes for Lignocellulosic Hydrolysis under Solid-State Fermentation. Bioresour. Bioprocess. 2018, 5, 31. [CrossRef]

132. Ashok, A.; Doriya, K.; Rao, D.R.M.; Kumar, D.S. Design of Solid State Bioreactor for Industrial Applications: An Overview to Conventional Bioreactors. Biocatal. Agric. Biotechnol. 2017, 9, 11-18. [CrossRef]

133. Singh, S.K.; Sczakas, G.; Soccol, C.R.; Pandey, A. Production of Enzymes by Solid-state Fermentation. In Current Developments in Solid-state Fermentation; Pandey, A., Soccol, C.R., Larroche, C., Eds.; Springer: New York, NY, USA, 2008; pp. 183-204, ISBN 978-0-387-75213-6.

134. Abdel-Azeem, A.M.; Abdel-Azeem, M.A.; Abdul-Hadi, S.Y.; Darwish, A.G. Aspergillus: Biodiversity, Ecological Significances, and Industrial Applications. In Recent Advancement in White Biotechnology Through Fungi: Volume 1: Diversity and Enzymes Perspectives; Yadav, A.N., Mishra, S., Singh, S., Gupta, A., Eds.; Fungal Biology; Springer International Publishing: Cham, Switzerland, 2019; pp. 121-179, ISBN 978-3-030-10480-1.

135. Senthivelan, T.; Kanagaraj, J.; Panda, R.C. Recent Trends in Fungal Laccase for Various Industrial Applications: An Eco-Friendly Approach-A Review. Biotechnol. Bioprocess Eng. 2016, 21, 19-38. [CrossRef]

136. Niladevi, K.N. Ligninolytic Enzymes. In Biotechnology for Agro-Industrial Residues Utilisation: Utilisation of Agro-Residues; nee'Nigam, P.S., Pandey, A., Eds.; Springer: Dordrecht, The Netherlands, 2009; pp. 397-414, ISBN 978-1-4020-9942-7.

137. Xu, X.; Lin, M.; Zang, Q.; Shi, S. Solid State Bioconversion of Lignocellulosic Residues by Inonotus Obliquus for Production of Cellulolytic Enzymes and Saccharification. Bioresour. Technol. 2018, 247, 88-95. [CrossRef] [PubMed]

138. Dave, B.R.; Sudhir, A.P.; Subramanian, R.B. Purification and Properties of an Endoglucanase from Thermoascus Aurantiacus. Biotechnol. Rep. Amst. Neth. 2015, 6, 85-90. [CrossRef]

139. Yeoman, C.J.; Han, Y.; Dodd, D.; Schroeder, C.M.; Mackie, R.I.; Cann, I.K.O. Thermostable Enzymes as Biocatalysts in the Biofuel Industry. Adv. Appl. Microbiol. 2010, 70, 1-55. [CrossRef]

140. Grassick, A.; Murray, P.G.; Thompson, R.; Collins, C.M.; Byrnes, L.; Birrane, G.; Higgins, T.M.; Tuohy, M.G. Three-Dimensional Structure of a Thermostable Native Cellobiohydrolase, CBH IB, and Molecular Characterization of the Cel7 Gene from the Filamentous Fungus, Talaromyces Emersonii. Eur. J. Biochem. 2004, 271, 4495-4506. [CrossRef]

141. Vattem, D.A.; Shetty, K. Ellagic Acid Production and Phenolic Antioxidant Activity in Cranberry Pomace (Vaccinium macrocarpon) Mediated by Lentinus Edodes Using a Solid-State System. Process Biochem. 2003, 39, 367-379. [CrossRef]

142. Ambriz-Pérez, D.L.; Leyva-López, N.; Gutierrez-Grijalva, E.P.; Heredia, J.B. Phenolic Compounds: Natural Alternative in Inflammation Treatment. A Review. Cogent Food Agric. 2016, 2, 1131412. [CrossRef]

143. Shahzadi, T.; Anwar, Z.; Iqbal, Z.; Anjum, A.; Aqil, T.; Bakhtawar Afzal, A.; Kamran, M.; Mehmood, S.; Irshad, M. Induced Production of Exoglucanase, and $\beta$-Glucosidase from Fungal Co-Culture of T. Viride and G. Lucidum. Adv. Biosci. Biotechnol. 2014, 5, 426-433. [CrossRef]

144. Tišma, M.; Jurić, A.; Bucić-Kojić, A.; Panjičko, M.; Planinić, M. Biovalorization of Brewers' Spent Grain for the Production of Laccase and Polyphenols. J. Inst. Brew. 2018, 124, 182-186. [CrossRef]

145. Akpinar, M.; Ozturk Urek, R. Induction of Fungal Laccase Production under Solid State Bioprocessing of New Agroindustrial Waste and Its Application on Dye Decolorization. 3 Biotech 2017, 7, 98. [CrossRef] [PubMed]

146. Ghosh, P.; Ghosh, U. Bioconversion of Agro-Waste to Value-Added Product Through Solid-State Fermentation by a Potent Fungal Strain Aspergillus flavus PUF5. In Utilization and Management of Bioresources; Ghosh, S.K., Ed.; Springer: Singapore, 2018; pp. 291-299.

147. Murugesan, K.; Nam, I.-H.; Kim, Y.-M.; Chang, Y.-S. Decolorization of Reactive Dyes by a Thermostable Laccase Produced by Ganoderma Lucidum in Solid State Culture. Enzyme Microb. Technol. 2007, 40, 1662-1672. [CrossRef] 
148. Sharma, A.; Gupta, V.; Khan, M.; Balda, S.; Gupta, N.; Capalash, N.; Sharma, P. Flavonoid-Rich Agro-Industrial Residues for Enhanced Bacterial Laccase Production by Submerged and Solid-State Fermentation. 3 Biotech 2017, 7, 200. [CrossRef]

149. Pandey, S.; Srivastava, M.; Shahid, M.; Kumar, V.; Singh, A.; Trivedi, S.; Srivastava, Y.K. Trichoderma Species Cellulases Produced by Solid State Fermentation. J. Data Min. Genom. Proteom. 2015, 6, 170. [CrossRef]

150. Marques, G.L.; dos Santos Reis, N.; Silva, T.P.; Ferreira, M.L.O.; Aguiar-Oliveira, E.; de Oliveira, J.R.; Franco, M. Production and Characterisation of Xylanase and Endoglucanases Produced by Penicillium Roqueforti ATCC 10110 Through the Solid-State Fermentation of Rice Husk Residue. Waste Biomass Valorization 2018, 9, 2061-2069. [CrossRef]

151. Saqib, A.A.N.; Hassan, M.; Khan, N.F.; Baig, S. Thermostability of Crude Endoglucanase from Aspergillus Fumigatus Grown under Solid State Fermentation (SSF) and Submerged Fermentation (SmF). Process Biochem. 2010, 45, 641-646. [CrossRef]

152. Mahmood, R.T.; Asad, M.J.; Mehboob, N.; Mushtaq, M.; Gulfraz, M.; Asgher, M.; Minhas, N.M.; Hadri, S.H. Production, Purification, and Characterization of Exoglucanase by Aspergillus Fumigatus. Appl. Biochem. Biotechnol. 2013, 170, 895-908. [CrossRef]

153. Singla, D.; Taggar, M.S. Production of Cellulases by Solid State Fermentation of Different Agricultural Residues Using Humicola Insolens MTCC 1433. Int. J. Curr. Microbiol. Appl. Sci. 2017, 6, 1409-1418. [CrossRef]

154. Garcia, N.F.L.; da Silva Santos, F.R.; Gonçalves, F.A.; da Paz, M.F.; Fonseca, G.G.; Leite, R.S.R. Production of $\beta$-Glucosidase on Solid-State Fermentation by Lichtheimia Ramosa in Agroindustrial Residues: Characterization and Catalytic Properties of the Enzymatic Extract. Electron. J. Biotechnol. 2015, 18, 314-319. [CrossRef]

155. Leite, R.S.R.; Alves-Prado, H.F.; Cabral, H.; Pagnocca, F.C.; Gomes, E.; Da-Silva, R. Production and Characteristics Comparison of Crude $\beta$-Glucosidases Produced by Microorganisms Thermoascus Aurantiacus e Aureobasidium Pullulans in Agricultural Wastes. Enzyme Microb. Technol. 2008, 43, 391-395. [CrossRef]

156. Pandya, J.J.; Gupte, A. Production of Xylanase under Solid-State Fermentation by Aspergillus Tubingensis JP-1 and Its Application. Bioprocess Biosyst. Eng. 2012, 35, 769-779. [CrossRef] [PubMed]

157. Dhiman, S.S.; Sharma, J.; Battan, B. Pretreatment Processing of Fabrics by Alkalothermophilic Xylanase from Bacillus Stearothermophilus SDX. Enzyme Microb. Technol. 2008, 43, 262-269. [CrossRef]

158. Park, Y.; Kang, S.; Lee, J.; Hong, S.; Kim, S. Xylanase Production in Solid State Fermentation by Aspergillus Niger Mutant Using Statistical Experimental Designs. Appl. Microbiol. Biotechnol. 2002, 58, 761-766. [CrossRef]

159. Umsza-Guez, M.A.; Díaz, A.B.; Ory, I.D.; Blandino, A.; Gomes, E.; Caro, I. Xylanase Production by Aspergillus Awamori under Solid State Fermentation Conditions on Tomato Pomace. Braz. J. Microbiol. 2011, 42, 1585-1597. [CrossRef]

160. Gaffney, M.; Doyle, S.; Murphy, R. Optimization of Xylanase Production by Thermomyces Lanuginosus in Solid State Fermentation. Biosci. Biotechnol. Biochem. 2009, 73, 2640-2644. [CrossRef]

161. Tan, D.; Yin, J.; Chen, G.-Q. Production of Polyhydroxyalkanoates. In Current Developments in Biotechnology and Bioengineering; Pandey, A., Negi, S., Soccol, C.R., Eds.; Elsevier: Amsterdam, The Netherlands, 2017; pp. 655-692, ISBN 978-0-444-63662-1.

162. Collins, T.; Gerday, C.; Feller, G. Xylanases, Xylanase Families and Extremophilic Xylanases. FEMS Microbiol. Rev. 2005, 29 , 3-23. [CrossRef]

163. Helkar, P.B.; Sahoo, A.; Patil, N. Review: Food Industry By-Products Used as a Functional Food Ingredients. Int. J. Waste Resour. 2016, 6, 1-6. [CrossRef]

164. Beres, C.; Costa, G.N.S.; Cabezudo, I.; da Silva-James, N.K.; Teles, A.S.C.; Cruz, A.P.G.; Mellinger-Silva, C.; Tonon, R.V.; Cabral, L.M.C.; Freitas, S.P. Towards Integral Utilization of Grape Pomace from Winemaking Process: A Review. Waste Manag. 2017, 68, 581-594. [CrossRef]

165. Vuolo, M.M.; Lima, V.S.; Maróstica Junior, M.R. Chapter 2-Phenolic Compounds: Structure, Classification, and Antioxidant Power. In Bioactive Compounds; Campos, M.R.S., Ed.; Woodhead Publishing: Cambridge, UK, 2019; pp. 33-50, ISBN 978-0-12814774-0.

166. Antonic, B.; Jancikova, S.; Dordevic, D.; Tremlova, B. Apple Pomace as Food Fortification Ingredient: A Systematic Review and Meta-Analysis. J. Food Sci. 2020, 85, 2977-2985. [CrossRef]

167. Martínez-Ávila, G.C.; Aguilera-Carbó, A.F.; Rodríguez-Herrera, R.; Aguilar, C.N. Fungal Enhancement of the Antioxidant Properties of Grape Waste. Ann. Microbiol. 2012, 62, 923-930. [CrossRef]

168. Aguilar, C.N.; Aguilera-Carbo, A.; Robledo, A.; Ventura, J.; Belmares, R.; Martinez, D.; Rodríguez-Herrera, R.; Contreras, J. Production of Antioxidant Nutraceuticals by Solid-State Cultures of Pomegranate (Punica granatum) Peel and Creosote Bush (Larrea tridentata) Leaves. Food Technol. Biotechnol. 2008, 46, 218-222.

169. Kumari, D.; Singh, R. Pretreatment of Lignocellulosic Wastes for Biofuel Production: A Critical Review. Renew. Sustain. Energy Rev. 2018, 90, 877-891. [CrossRef]

170. Mahesh, M.S.; Mohini, M. Biological Treatment of Crop Residues for Ruminant Feeding: A Review. Afr. J. Biotechnol. $2013,12$. [CrossRef]

171. Jobling, M. Can Waste Re-Cycling Increase the Sustainability of Animal Feeds? Fiskerikandidaten 2019, 16-21.

172. Godoy, M.G.; Amorim, G.M.; Barreto, M.S.; Freire, D.M.G. Chapter 122-Agricultural Residues as Animal Feed: Protein Enrichment and Detoxification Using Solid-State Fermentation. In Current Developments in Biotechnology and Bioengineering; Pandey, A., Larroche, C., Soccol, C.R., Eds.; Elsevier: Amsterdam, The Netherlands, 2018; pp. 235-256, ISBN 978-0-444-63990-5.

173. EUR-Lex2_L:2004:165:TOC2—EN2—EUR-Lex. Available online: https:/ / eur-lex.europa.eu/legal-content/EN/TXT/?uri=OJ: L:2004:165:TOC (accessed on 14 April 2021). 